\title{
A Review of Removal of Pollutants from Water/Wastewater Using Different Types of Nanomaterials
}

\author{
M. T. Amin, A. A. Alazba, and U. Manzoor \\ Alamoudi Water Research Chair, King Saud Universtiy, P.O. Box 2460, Riyadh 11451, Saudi Arabia \\ Correspondence should be addressed to M. T. Amin; mtamin@ksu.edu.sa
}

Received 2 January 2014; Revised 3 March 2014; Accepted 3 March 2014; Published 23 June 2014

Academic Editor: A. G. Barbosa de Lima

Copyright ( 2014 M. T. Amin et al. This is an open access article distributed under the Creative Commons Attribution License, which permits unrestricted use, distribution, and reproduction in any medium, provided the original work is properly cited.

\begin{abstract}
The rapidly increasing population, depleting water resources, and climate change resulting in prolonged droughts and floods have rendered drinking water a competitive resource in many parts of the world. The development of cost-effective and stable materials and methods for providing the fresh water in adequate amounts is the need of the water industry. Traditional water/wastewater treatment technologies remain ineffective for providing adequate safe water due to increasing demand of water coupled with stringent health guidelines and emerging contaminants. Nanotechnology-based multifunctional and highly efficient processes are providing affordable solutions to water/wastewater treatments that do not rely on large infrastructures or centralized systems. The aim of the present study is to review the possible applications of the nanoparticles/fibers for the removal of pollutants from water/wastewater. The paper will briefly overview the availability and practice of different nanomaterials (particles or fibers) for removal of viruses, inorganic solutes, heavy metals, metal ions, complex organic compounds, natural organic matter, nitrate, and other pollutants present in surface water, ground water, and/or industrial water. Finally, recommendations are made based on the current practices of nanotechnology applications in water industry for a stand-alone water purification unit for removing all types of contaminants from wastewater.
\end{abstract}

\section{Introduction}

Water has a broad impact on all aspects of human life including but not limited to health, food, energy, and economy. In addition to the environmental, economic, and social impacts of poor water supply and sanitation [1-4], the supply of fresh water is essential for the safety of children and the poor $[5,6]$. It is estimated that $10-20$ million people die every year due to waterborne and nonfatal infection causes death of more than 200 million people every year [7]. Every day, about $5,000-6,000$ children die due to the water-related problem of diarrhea $[8,9]$. There are currently more than 0.78 billion people around the world who do not have access to safe water resources [10] resulting in major health problems. It is estimated that more than one billion people in the world lack access to safe water and within couple of decades the current water supply will decrease by one-third.

The portion of total run-off which constitutes stable run-off flow is considered as the freshwater resource upon which humans depend. This stable fresh water flow has been estimated at $12,500-15,000 \mathrm{~km}^{3}$ per year $[11,12]$, from which $4000 \mathrm{~km}^{3}$ per year is considered to be the total freshwater for irrigation, industry, and domestic purposes [13], and which is estimated to increase to a range of $4300-5000 \mathrm{~km}^{3}$ per year in 2025 [14-16]. Alternatively, only accessible fresh water is $0.5 \%$ of the world's 1.4 billion $\mathrm{Km}^{3}$ of water which is furthermore poorly distributed across the globe [17].

There is limited possibility of an increase in the supply of fresh water due to competing demands of increasing populations throughout the world; also, water-related problems are expected to increase further due to climate changes and due to population growth over the next two decades [18]. It is estimated that worldwide population will increase by about 2.9 billion people between now and 2050 (according to UN's average projections) [15]. Shortage of fresh water supply is also a result of the exploitation of water resources for domestic, industry, and irrigation purposes in many 
parts of the world [19]. The pressure on freshwater resources due to the increasing world's demand of food, energy, and so forth $[20,21]$ is increasing more and more due to population growth and threats of climate change. Polluting surface/ground water sources is another cause of reduced fresh water supplies [22-24]. Aquifers around the world are depleting and being polluted due to multiple problems of saltwater intrusion, soil erosion, inadequate sanitation, contamination of ground/surface waters by algal blooms, detergents, fertilizers, pesticides, chemicals, heavy metals, and so forth [25-28].

The occurrence of new/emerging microcontaminants (e.g., endocrine disrupting compounds (EDCs)) in polluted water/wastewater has rendered existing conventional water/wastewater treatment plants ineffective to meet the environmental standards. The discharge of these compounds into the aquatic environment has affected all living organisms. The traditional materials and treatment technologies like activated carbon, oxidation, activated sludge, nanofiltration (NF), and reverse osmosis (RO) membranes are not effective to treat complex and complicated polluted waters comprising pharmaceuticals, personal care products, surfactants, various industrial additives, and numerous chemicals purported. The conventional water treatment processes are not able to address adequately the removal of a wide spectrum of toxic chemicals and pathogenic microorganisms in raw water.

This is the right time to address water problems since aquifers around the world are depleting due to multiple factors such as saltwater intrusion and contamination from surface waters. Using better purification technologies can reduce problems of water shortages, health, energy, and climate change. A considerable saving of potable water can be achieved through reuse of wastewater which, in turn, requires the development materials and methods which are efficient, cost-effective, and reliable. Although dilution of complex wastewater effluents can help decreasing the load of micropollutants downstream [29, 30], however, much of them pass through conventional water treatment due to occurrence of these substances in micro- or even in nanograms per liter.

Biological treatment systems such as activated sludge and biological trickling filters are unable to remove a wide range of emerging contaminants and most of these compounds remain soluble in the effluent [31-33]. Physicochemical treatments such as coagulation, flocculation, or lime softening proved to be ineffective for removing different EDCs and pharmaceutical compounds in various studies [34-36]. Chlorination, though providing residual protection against regrowth of bacteria and pathogens $[37,38]$, results in undesirable tastes and odors [39] in addition to the forming of different disinfection by-products (DBPs) in portable drinking water [40-43]. Ozonation has been considered to be a less attractive alternative due to expensive costs and short lifetime. Both ultraviolet (UV) photolysis and ion exchange, though being advanced type of treatments, are not feasible alternatives for micropollutants removal [44].

Membrane processes like microfiltration, ultrafiltration, $\mathrm{NF}$, and $\mathrm{RO}$, which are pressure-driven filtration processes, are considered as some new highly effective processes [44-49]. These are considered as alternative methods of removing huge amounts of organic micropollutants [5052]. Water/wastewater treatment by membrane techniques is cost-effective and technically feasible and can be better alternatives for the traditional treatment systems since their high efficiency in removal of pollutants meets the high environmental standards [53]. NF and RO have proved to be quite effective filtration technologies for removal of micropollutants $[54,55]$. RO is relatively more effective than NF but higher energy consumption in $\mathrm{RO}$ makes it less attractive than NF where removal of pollutants is caused by different mechanisms including convection, diffusion (sieving), and charge effects [56]. Although NF based membrane processes are quite effective in removing huge loads of micropollutants [57], advanced materials and treatment methods are required to treat newly emerging micropollutants.

Since the water industry is required to produce drinking water of high quality, there is a clear need for the development of cost-effective and stable materials and methods to address the challenges of providing the fresh water in adequate amounts. There are inventions of new treatment methods; however, they need to be stable, economical, and more effective as compared with the already existing techniques. For this, traditional treatment technologies have to be modernized, that is, updated or modified or replaced by developing materials and methods which are efficient, cost-effective, and reliable. This is particularly important to achieve a considerable potable water savings through reuse of wastewater in addition to tackling the day-by-day worsening quality of drinking water.

Nanotechnology has been considered effective in solving water problems related to quality and quantity [58]. Nanomaterials (e.g., carbon nanotubes (CNTs) and dendrimers) are contributing to the development of more efficient treatment processes among the advanced water systems [59]. There are many aspects of nanotechnology to address the multiple problems of water quality in order to ensure the environmental stability. This study provides a unique perspective on basic research of nanotechnology for water/wastewater treatment and reuse by focusing on challenges of future research.

The paper has three main sections following the introduction which briefly discusses the traditional and current practices in water/wastewater treatment. Section 2 describes mainly the properties and types of nanomaterials and their importance in water/wastewater treatment. Section 3 discusses different types of nanomaterials focusing on membranes for treating a variety of pollutants in water/wastewater. The application of nanomaterials is reviewed based on their functions in unit operation processes. Section 4 provides a summary and outlook in the form of conclusions and recommendations for their full-scale application.

\section{Nanotechnology for Water/Wastewater Purification}

There are rising demands of clean water throughout the world as freshwater sources/resources are depleting due to 
prolonged droughts, increasing population, climate changes threats, and strict water quality standards $[60,61]$. Masses in developing countries are using unconventional water sources (e.g., stormwater, contaminated fresh water, brackish water) due to limited and depleting fresh water supplies. The existing water treatment systems, distribution systems, and disposable habits coupled with huge centralized schemes are no more sustainable. The current researches do not adequately address the practices that guarantee the availability of water for all users in accordance with the stringent water quality standards [62].

Several commercial and noncommercial technological developments are employed on daily basis but nanotechnology has proved to be one of the advanced ways for water/waste water treatment. Developments in nanoscale research have made it possible to invent economically feasible and environmentally stable treatment technologies for effectively treating water/wastewater meeting the ever increasing water quality standards. Advances in nanotechnology have provided the opportunities to meet the fresh water demands of the future generations. It is suggested that nanotechnology can adequately address many of the water quality issues by using different types of nanoparticles and/or nanofibers [63]. Nanotechnology uses materials of sizes smaller than $100 \mathrm{~nm}$ in at least one dimension (Figure 1) meaning at the level of atoms and molecules as compared with other disciplines such as chemistry, engineering, and materials science $[64,65]$.

At this scale, materials possess novel and significantly changed physical, chemical, and biological properties mainly due to their structure, higher surface area-to-volume ratio offering treatment and remediation, sensing and detection, and pollution prevention $[66,67]$. These unique properties of nanomaterials, for example, high reactivity and strong sorption, are explored for application in water/wastewater treatment based on their functions in unit operations as highlighted in Table 1 [68].

Nanoparticles can penetrate deeper and thus can treat water/wastewater which is generally not possible by conventional technologies [69]. The higher surface area-tovolume ratio of nanomaterials enhances the reactivity with environmental contaminants.

In the context of treatment and remediation, nanotechnology has the potential to provide both water quality and quantity in the long run through the use of, for example, membranes enabling water reuse, desalination. In addition, it yields low-cost and real-time measurements through the development of continuous monitoring devices [70, 71]. Nanoparticles, having high absorption, interaction, and reaction capabilities, can behave as colloid by mixing mixed with aqueous suspensions and they can also display quantum size effects [72-76]. Energy conservation leading to cost savings is possible due to their small sizes; however, overall usage cost of the technology should be compared with other techniques in the market [77]. Figure 2 depicts some of the different types of nanomaterials that can be used in water/wastewater treatment [78-80].

Nanomaterials have effectively contributed to the development of more efficient and cost-effective water filtration processes since membrane technology is considered as one of the advanced water/wastewater treatment processes [81-91]. Nanoparticles have been frequently used in the manufacturing of membranes, allowing permeability control and foulingresistance in various structures and relevant functionalities $[92,93]$. Both polymeric and inorganic membranes are manufactured by either assembling nanoparticles into porous membranes or blending process [94-96]. The examples of nanomaterials used in this formation include, for example, metal oxide nanoparticles like $\mathrm{TiO}_{2}$. CNTs have resulted in desired outputs of improved permeability, inactivation of bacteria, and so forth $[97,98]$.

Finally, nanofibrous media have also been used to improve the filtration systems due to their high permeability and small pore size properties [99]. They are synthesized by a new and efficient fabrication process, namely, electrospinning and may exhibit different properties depending on the selected polymers [100]. In short, the development of different nanomaterials like nanosorbents, nanocatalysts, zeolites, dendrimers, and nanostructured catalytic membranes has made it possible to disinfect disease causing microbes, removing toxic metals, and organic and inorganic solutes from water/wastewater. An attempt is made to highlight the factors that may influence the efficiency of the removal processes based on the available literature in the following section.

\section{Pollutants Removal Using Different Nanomaterials}

3.1. Disinfection. Biological contaminants can be classified into three categories, namely, microorganisms, natural organic matter (NOM), and biological toxins. Microbial contaminants include human pathogens and free living microbes [101-105]. The removal of cyanobacterial toxins is an issue in conventional water treatment systems [106, 107]. Many adsorbents including activated carbon have reasonably good removal efficiencies and again a number of factors influence the removal process [108-111].

Contamination from bacteria, protozoans, and viruses is possible in both ground and surface water. The toxicity of the standard chlorine chemical disinfection in addition to the carcinogenic and very harmful by-products formation is already mentioned. Chlorine dioxide is expensive and results in the production of hazardous substances like chlorite and chlorate in manufacturing process. Ozone, on the other hand, has no residual effects but produces unknown organic reaction products. For UV disinfection, longer exposure time is required for effectiveness and also there is no residual effect. Despite advances in disinfection technology, outbreaks from waterborne infections are still occurring. So, advanced disinfection technologies must, at least, eliminate the emerging pathogens, in addition to their suitability for large-scale adoption. There are many different types of nanomaterials such as Ag, titanium, and zinc capable of disinfecting waterborne disease-causing microbes. Due to their charge capacity, they possess antibacterial properties. $\mathrm{TiO}_{2}$ photocatalysts and metallic and metal-oxide nanoparticles are among the most promising nanomaterials with antimicrobial properties. 


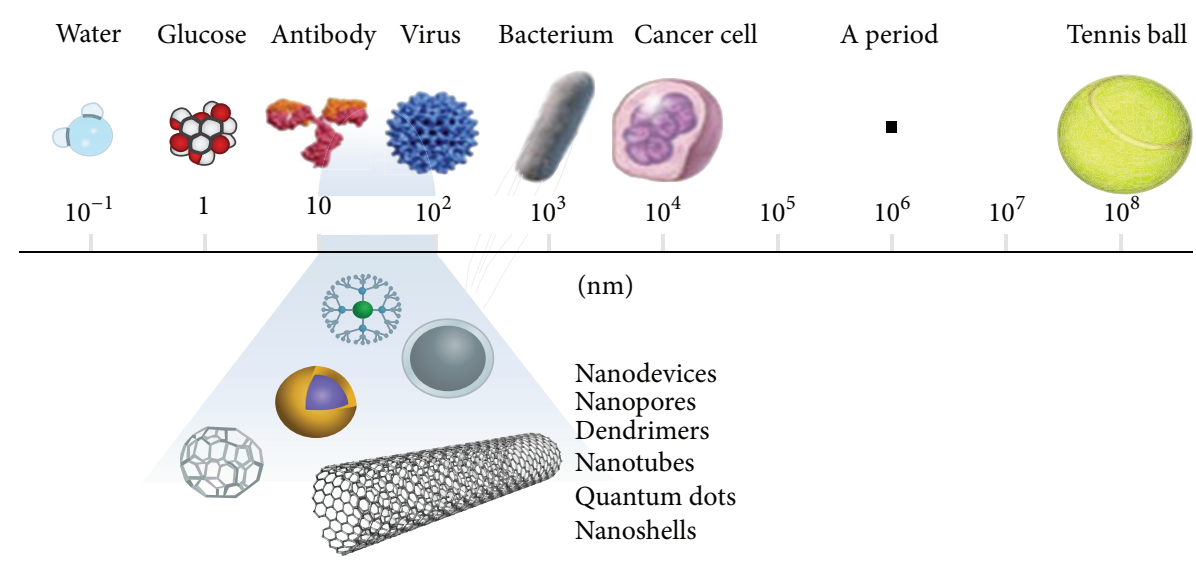

FIGURE 1: A size comparison of nanoparticle with other larger-sized materials.

TABLE 1: Examples of potential applications of nanotechnology in water/wastewater treatment.

\begin{tabular}{|c|c|c|}
\hline Applications & Examples of nanomaterials & Some of novel properties \\
\hline Adsorption & CNTs/nanoscale metal oxide and nanofibers & $\begin{array}{l}\text { High specific surface area and assessable adsorption sites, } \\
\text { selective and more adsorption sites, short intraparticle diffusion } \\
\text { distance, tunable surface chemistry, easy reuse, and so forth. }\end{array}$ \\
\hline Disinfection & Nanosilver/titanium dioxide $\left(\mathrm{Ag} / \mathrm{TiO}_{2}\right)$ and CNTs & $\begin{array}{l}\text { Strong antimicrobial activity, low toxicity and cost, high } \\
\text { chemical stability ease of use, and so forth. }\end{array}$ \\
\hline Photocatalysis & Nano- $\mathrm{TiO}_{2}$ and Fullerene derivatives & $\begin{array}{l}\text { Photocatalytic activity in solar spectrum, low human toxicity, } \\
\text { high stability and selectivity, low cost, and so forth. }\end{array}$ \\
\hline Membranes & Nano-Ag/TiO $/ 2$ Zeolites/Magnetite and CNTs & $\begin{array}{l}\text { Strong antimicrobial activity, hydrophilicity low toxicity to } \\
\text { humans, high mechanical and chemical stability, high } \\
\text { permeability and selectivity, photocatalytic activity, and so forth. }\end{array}$ \\
\hline
\end{tabular}

The efficacy of metal ions in water disinfection has been highlighted by many researchers [112]. This part of the paper covers the application of these antimicrobial nanomaterials for water disinfection.

3.1.1. Silver Nanoparticles. Silver is the most widely used material due to its low toxicity and microbial inactivation in water [113-116] with well-reported antibacterial mechanism $[117,118]$. Silver nanoparticles are derived from its salts like silver nitrate and silver chloride, and their effectiveness as biocides is documented in the literature [119-123]. Though the antibacterial effect is size dependent [124], smaller Ag nanoparticles $(8 \mathrm{~nm})$ were most effective, while larger particle size $(11-23 \mathrm{~nm})$ results in lower bactericidal activity [125]. Also, truncated triangular silver nanoplates exhibited better antibacterial effects than the spherical and rod-shaped nanoparticles indicating their shape dependency [126]. The mechanisms involved during the bactericidal effects of Ag nanoparticles include, for example, the formation of free radicals damaging the bacterial membranes [127, 128], interactions with DNA, adhesion to cell surface altering the membrane properties, and enzyme damage $[122,129,130]$.

Immobilized nanoparticles have gained importance due to high antimicrobial activity [131]. Embedded Ag nanoparticles have been reported as very effective against both Gram-positive and Gram-negative bacteria [63]. In a study, the cellulose acetate fibers embedded with Ag nanoparticles by direct electrospinning method [132] were shown effective against both types of bacteria. Ag nanoparticles are also incorporated into different types of polymers for the production of antimicrobial nanofibers and nanocomposites [133-135]. Poly ( $\varepsilon$-caprolactone-) based polyurethane nanofiber mats containing Ag nanoparticles were prepared as antimicrobial nanofilters in a study [136]. Different types of nanofibers containing Ag nanoparticles are prepared for antimicrobial application and exhibited very good antimicrobial properties [137-139]. Water filters prepared by polyurethane's foam coated with Ag nanofibers have shown good antibacterial properties against Escherichia coli (E. coli) [112].

There are other examples of low-cost potable microfilters prepared by incorporating Ag nanoparticles that can be used in remote areas in developing countries [140]. Ag nanoparticles also find their applications in water filtration membranes, for example, in polysulfone membranes [141], for biofouling reduction and have proved effective against variety of bacteria and viruses [142-148]. These Ag nanoparticles laden membranes had good antimicrobial activities against E. coli, Pseudomonas, and so forth $[149,150]$.

Finally, Ag nanocatalyst alone and incorporate with carbon covered in alumina has been demonstrated as efficient for degradation of microbial contaminants in water [151]. 


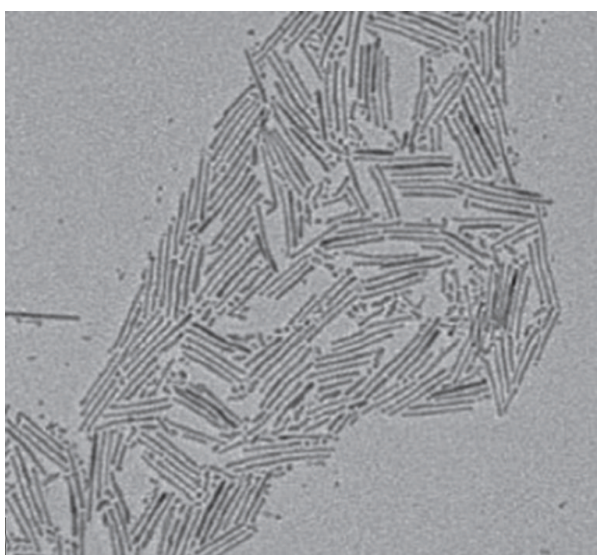

(a) TEM image of $\mathrm{TiO}_{2}$ nanocrystals

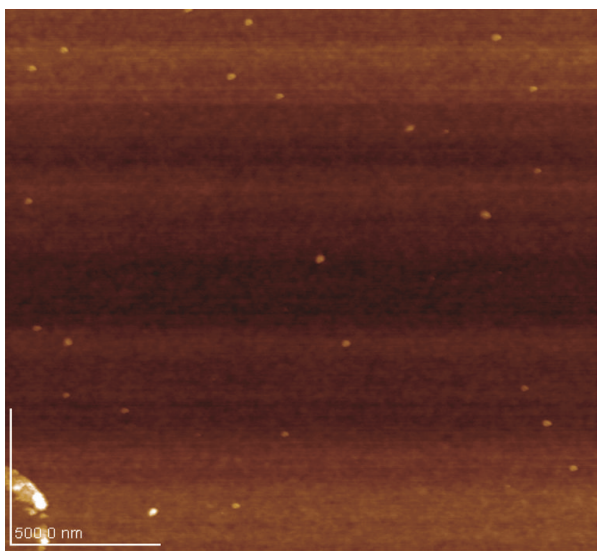

(c) AFM image of Zinc oxide $(\mathrm{ZnO})$ nanoparticles

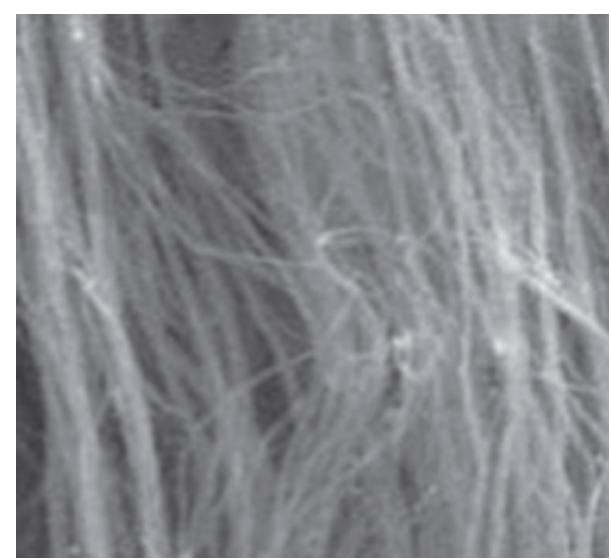

(b) SEM images of aligned CNTs

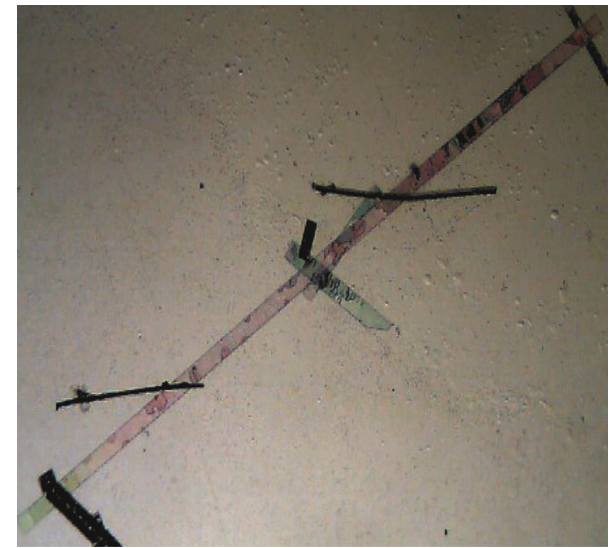

(d) Optical microscope image of Sn-doped $\mathrm{ZnO}$ nanobelts

FIGURE 2: Examples of different types of nanomaterials including particles, crystals, tube, and belts.

Although Ag nanoparticles have been used efficiently for inactivating bacteria and viruses as well as reducing membrane biofouling, their long-term efficacy against membrane biofouling has not been reported mainly due to loss of silver ions with time $[152,153]$. So, further work to reduce this loss of silver ions is required for long-term control of membrane biofouling. Alternatively, doping of Ag nanoparticles with other metallic nanoparticles or its composites with metaloxide nanoparticles can solve the issue and this could also lead to the parallel removal of inorganic/organic compounds from water/wastewater.

3.1.2. $\mathrm{TiO}_{2}$ Nanoparticles. $\mathrm{TiO}_{2}$ nanoparticles are among the emerging and most promising photocatalysts for water purification $[154,155]$. The basic mechanism of a semiconductorbased photocatalysts like low-cost $\mathrm{TiO}_{2}$ having good photoactivity and nontoxicity [156] involves the production of highly reactive oxidants, such as $\mathrm{OH}$ radicals, for disinfection of microorganisms, bacteria, fungi, algae, viruses, and so forth [157-165]. $\mathrm{TiO}_{2}$, after 8 hours of simulated solar exposure, has been reported to reduce the viability of several waterborne pathogens such as protozoa, fungi, E. coli, and Pseudomonas aeruginosa [166]. A complete inactivation of fecal coliforms under sunlight is reported in a study expressing the photocatalytic disinfection efficiency of $\mathrm{TiO}_{2}$ [167].

The limited photocatalytic capability of $\mathrm{TiO}_{2}$, that is, only under UV light, has improved drastically by extending its optical absorbance to the visible-light region $[168,169]$. This was achieved by doping transition metals [170] and anionic nonmetals such as nitrogen [171-180], carbon [181-187], sulfur [188-190], or fluorine [191] into $\mathrm{TiO}_{2}$. Recently, Ag doping of $\mathrm{TiO}_{2}$ has resulted in improved bacterial inactivation either by complete removal or decreased time of $E$. coli inactivation thereby enhancing disinfection under UV wavelengths and solar radiations [192-197].

As highlighted, the synthesis of visible-light-activated $\mathrm{TiO}_{2}$ nanoparticles has attracted considerable interest [198], and $\mathrm{TiO}_{2}$ nanoparticles and nanocrystallines irradiated with UV-visible light exhibited strong bactericidal activity against E. coli [199-202]. Metal-doped $\mathrm{TiO}_{2}$ nanoparticles, sulfur, and iron in couple of studies have shown strong antibacterial effects against $E$. coli $[203,204]$. $\mathrm{TiO}_{2}$ was further modified by nanoparticles of transition metal oxides and nanostructured 
$\mathrm{TiO}_{2}$ photocatalysts showed great potential for water disinfection. For example, metal-ion-modified nitrogen-doped $\mathrm{TiO}_{2}$ nanoparticle photocatalysts (palladium (Pd) in a study) have shown enhanced disinfection efficiency against $E$. coli (Gram-negative bacterium), Pseudomonas aeruginosa, and Bacillus subtilis spores due to photocatalytic oxidation under visible-light illumination [205, 206].

Nitrogen-doped $\mathrm{TiO}_{2}$ nanoparticles catalysts have proved their efficiency for degradation of microbial contaminants in water [151]. Nanostructured $\mathrm{TiO}_{2}$ films and membranes are capable of disinfecting microorganisms in addition to the decomposition of organic pollutants under UV and visiblelight irradiation [207]. Due to its stability in water, $\mathrm{TiO}_{2}$ can be incorporated in thin films or membrane filters for water filtration $[208,209] . \mathrm{TiO}_{2}$ nanorods and nanofilms exhibited a higher photocatalytic activity than commercial $\mathrm{TiO}_{2}$ nanoparticles and $\mathrm{TiO}_{2}$ thin films, respectively, for the photocatalytic inactivation of $E$. coli $[191,210,211]$. The inactivation mechanism of $E$. coli when using $\mathrm{TiO}_{2}$ thin films was also investigated by many researchers [212, 213]. In a study, $\mathrm{TiO}_{2}$ nanocomposites with multiwalled CNTs showed the complete inactivation of bacterial endospores (Bacillus cereus), compared to commercial $\mathrm{TiO}_{2}$ nanoparticles [214]. Immobilized $\mathrm{TiO}_{2}$ nanoparticle films successfully inactivated E. coli $\mathrm{K} 12$ in surface and distilled water [215]. $\mathrm{TiO}_{2}$ nanoparticles incorporated into an isotactic polypropylene polymeric matrix showed higher biocidal activity against Enterococcus faecalis and Pseudomonas aeruginosa [216].

The detailed review has demonstrated the antibacterial efficiency of $\mathrm{TiO}_{2}$ nanoparticles, but the actual underlying mechanisms are not well defined especially under visible light. In addition, composites of $\mathrm{TiO}_{2}$ nanoparticles by doping with other metallic nanoparticles have also shown their effectiveness, but the applications of using $\mathrm{TiO}_{2}$ nanofibers and thin films need to be investigated for the effective removal of both inorganic/organic compounds in addition to the disinfection.

3.1.3. CNTs and Others. CNTs have proved to be very effective in removing bacterial pathogens. CNTs (one of nanosorbents) which have been used for removal of biological impurities have received special attention for their excellent capabilities of removing biological contaminants from water [63]. CNTs possess antimicrobial characteristics against a wide range of microorganisms including bacteria such as $E$. coli and Salmonella [217-222] and viruses [223, 224]. The adsorption of cyanobacterial toxins on CNTs is also higher when compared with carbon-based adsorbents mainly due to large specific surface area, external diameter of CNTs, large composition of mesoporous volume, and so forth [225-228].

Researchers have attributed the antimicrobial effects of CNTs to their unique physical, cytotoxic, and surface functionalizing properties [229], their fibrous shape [230, 231], the size and length of the tubes, and number of layers (single- or multiwalled) $[155,232]$. The mechanisms of killing bacteria by CNTs are also due to the production of oxidative stress, disturbances to cell membrane, and so forth [233]. Although single-walled CNTs are more detrimental against microorganisms than multiwalled CNTs [234], dispersivity of CNTs is a more important parameter than length [235]. Many researchers observed an extremely high adsorption rate of bacteria by single-walled CNTs, in addition to their high sorption capacities by many researchers [236-244].

Filtration membranes containing radially aligned CNTs are very effective in removing both bacteria and viruses in very short time due to size exclusion and depth filtration [245-247] and thus enable such filters to be used as costeffective and point-of-use water disinfection devices. CNTs can also reduce membrane biofouling and a nanocomposite membrane of single-walled CNTs and polyvinyl-N-carbazole showed high inactivation of bacteria upon direct contact in a study [248]. Another example of controlling the biofouling in thin film nanocomposite membranes is the single-walled CNTs covalently bonded to thin film composite membrane surface which have exhibited moderate antibacterial properties [249].

Among the other nanomaterials for microbial disinfection, bifunctional ferrous oxide $\left(\mathrm{Fe}_{3} \mathrm{O}_{4}\right) @ \mathrm{Ag}$ and $\mathrm{Fe}_{3} \mathrm{O}_{4}$ $@ \mathrm{TiO}_{2}$ nanoparticles were employed successfully against pathogenic bacteria including E. coli, Staphylococcus epidermidis, and Bacillus subtilis thus covering both Gram-positive and Gram-negative bacteria as well as spores [250, 251]. Magnesium oxide nanoparticles were also used effectively as biocides against both Gram-positive and Gram-negative bacteria and bacterial spores $[252,253]$.Nanotungsten oxide and palladium-incorporated $\mathrm{ZnO}$ nanoparticles have shown good antibacterial properties at removal of $E$. coli from water [254, 255]. Nitrogen-doped $\mathrm{ZnO}$ and Zirconium oxide nanoparticles also have proved good antibacterial nanostructured materials $[151,256]$.

3.2. Desalination. Desalination is considered an important alternative for obtaining fresh water source. Though expensive, membrane based desalination processes cover most of the desalination capability out of which only $\mathrm{RO}$ accounts for $41 \%$ [257]. Parameters that control the desalination cost include maximizing the flux of water through membrane to minimize the fouling. Recent developments in membrane technology have resulted in energy efficiency in RO plants [258]. NF has also been evaluated for desalinating seawater [259].

Nanomaterials are very useful in developing more efficient and cheaper nanostructured and reactive membranes for water/wastewater treatment and desalination such as CNT filters [260]. Nanomaterials offer opportunities to control the cost of desalination and increase its energy efficiency and among these are CNTs [261, 262], zeolites [263, 264], and graphene [265-267]. The controlled synthesis of both the length and diameters of CNTs has enabled them to be used in RO membranes to achieve high water fluxes [268-270].

Thin film nanocomposite membranes containing Ag and $\mathrm{TiO}_{2}$ nanoparticles exhibited good salt rejection [150, 271]. Membrane permeability and salt rejection are shown to be effected by the number of coatings in $\mathrm{TiO}_{2} / \mathrm{Al}_{2} \mathrm{O}_{3}$ (aluminium oxide) composite ceramic membranes coated by iron 
oxide nanoparticles $\left(\mathrm{Fe}_{2} \mathrm{O}_{3}\right)[272,273]$. A high sodium chloride rejection was obtained by using alumina ceramic membranes fabricated with silica nanoparticles [274]. Zeolitebased membranes for RO have exhibited high flux with excellent ion rejection characteristics [275, 276]. Studies also have indicated the potential of graphene membranes for water desalination with higher fluxes than polymeric RO membranes [277].

Other nanostructures such as lyotropic liquid crystals and aquaporins also have exhibited high flux and selective water transportation [278-280]. Zeolite-polyamide thin film nanocomposite membranes offered new ways of designing $\mathrm{NF}$ and RO membranes with increased water permeability and high salt rejection $[275,281]$. The use of nanozeolites in thin film nanocomposite membranes has resulted in enhanced permeability and salt rejection [282, 283].

By grafting functional groups, such as carboxyl, at opening of CNTs, membranes have better selective rejection of some components but this has resulted in reduced permeability rendering CNTs incapable for desalination [281, 284, 285]. Hinds concluded a uniform CNT diameter of less than $0.8 \mathrm{~nm}$ for high salt rejection [286]. Nanocomposite membranes may serve as ideal membranes for desalination but a basic understanding of transport mechanism along with proper pore size selection by keeping the uniformity is required for economically feasible and commercially acceptable desalination membranes. The effects of real seawater feed on the efficiency of different nanomaterials need to be investigated in terms of long-term operation and maintenance of membrane performance.

3.3. Removal of Heavy Metals and Ions. Different types of nanomaterials have been introduced for removal of heavy metals from water/wastewater such as nanosorbents including CNTs, zeolites, and dendrimers and they have exceptional adsorption properties [63]. The ability of CNTs to adsorb heavy metals is reviewed by many researchers [287] such as $\mathrm{Cd}^{2+}$ [288], $\mathrm{Cr}^{3+}$ [289], $\mathrm{Pb}^{2+}$ [290], and $\mathrm{Zn}^{2+}$ [291] and metalloids such as arsenic (As) compounds [292]. Composites of CNTs with $\mathrm{Fe}$ and cerium oxide $\left(\mathrm{CeO}_{2}\right)$ have also been reported to remove heavy metal ions in few studies [293-295]. Cerium oxide nanoparticles supported on CNTs are used effectively to adsorb arsenic [289]. Fast adsorption kinetics of CNTs is mainly due to the highly accessible adsorption sites and the short intraparticle diffusion distance [287].

Metal based nanomaterials proved to be better in removing heavy metals than activated carbon [296], for example, adsorption of arsenic by using $\mathrm{TiO}_{2}$ nanoparticles and nanosized magnetite [297, 298]. The utilization of photocatalysts such as $\mathrm{TiO}_{2}$ nanoparticles has been investigated in detail to reduce toxic metal ions in water [299]. In a study, the effectiveness of nanocrystalline $\mathrm{TiO}_{2}$ in removing different forms of arsenic is elaborated and it has shown to be more effective photocatalyst than commercially available $\mathrm{TiO}_{2}$ nanoparticles with a maximum removal efficiency of arsenic at about neutral $\mathrm{pH}$ value [300]. A nanocomposite of $\mathrm{TiO}_{2}$ nanoparticles anchored on graphene sheet was also used to reduce $\mathrm{Cr}(\mathrm{VI})$ to $\mathrm{Cr}(\mathrm{III})$ in sunlight [301]. Similar $\mathrm{Cr}$ treatment was carried out by using palladium nanoparticles in another study [302].

The capability of removing heavy metals like As is also investigated by using iron oxide nanomaterials $\left(\mathrm{Fe}_{2} \mathrm{O}_{3}\right.$ and $\mathrm{Fe}_{3} \mathrm{O}_{4}$ ) as cost-effective adsorbents by many researchers [303-305]. Arsenic removal was also investigated by using high specific surface area of $\mathrm{Fe}_{3} \mathrm{O}_{4}$ nanocrystals [306]. Polymer-grafted $\mathrm{Fe}_{2} \mathrm{O}_{3}$ nanocomposite was effectively used to remove divalent heavy metal ions for copper, nickel, and cobalt over a pH range of 3 to 7 [307].

Bisphosphonate-modified magnetite nanoparticles were also used to remove the radioactive metal toxins, uranium dioxide $\left(\mathrm{UO}_{2}{ }^{2+}\right)$ with high efficiency from water [308]. Studies have shown that zero-valent iron or iron nanoparticles $\left(\mathrm{nZVI}\right.$ or $\mathrm{Fe}^{0}$ ) are very effective for the transformation of heavy metal ions such as $\mathrm{As}(\mathrm{III}), \mathrm{As}(\mathrm{V}), \mathrm{Pb}(\mathrm{II}), \mathrm{Cu}(\mathrm{II}), \mathrm{Ni}(\mathrm{II})$, and $\mathrm{Cr}(\mathrm{VI})$ [309-313]. Reduction of $\mathrm{Cr}(\mathrm{VI})$ to $\mathrm{Cr}(\mathrm{III})$ was also done by using nZVI and bimetallic nZVI nanoparticles in a study [314].

Novel self-assembled 3D flower-like iron oxide nanostructures were also used to successfully adsorb both $\mathrm{As}(\mathrm{V})$ and $\mathrm{Cr}(\mathrm{VI})$ [315]. The 3D nanostructures of $\mathrm{CeO}_{2}$ are used as good adsorbents for both As and $\mathrm{Cr}$ [316]. The efficiency of NaP1 zeolites was evaluated for removal of heavy metals (Cr(III), $\mathrm{Ni}(\mathrm{II}), \mathrm{Zn}(\mathrm{II}), \mathrm{Cu}(\mathrm{II})$, and $\mathrm{Cd}(\mathrm{II})$ ) from wastewater $[317,318]$. Dendritic polymers were also used for treatment of toxic metal ions [319]. The applicability of self-assembled monolayers on mesoporous supports for removing toxic metal ions novel was also evaluated by many researchers [320-322]. Biopolymers have been used for heavy metal remediation from aqueous wastes $[323,324]$. Chitosan nanoparticles for the sorption of $\mathrm{Pb}$ (II) were also used in one study [325].

$\mathrm{NF}$ is reviewed for the removal of cations and arsenic from ground/surface waters [326] and it has been shown very effective to remove uranium (VI) from sea water [327]. Novel nanofilter membranes prepared by assembling positive poly (allylamine hydrochloride) and negative poly (styrene sulfonate) onto porous alumina exhibited a high retention of $\mathrm{Ca}^{2+}$ and $\mathrm{Mg}^{2+}$ [85]. The incorporation of iron (hydr)oxide nanoparticles into porous carbon materials has made it possible to remove both inorganics and organics thus enabling such filters to be used as point-of-use applications [328, 329]. A dendrimer-UF system was used for the removal of $\mathrm{Cu}^{2+}$ and the complete removal from water was obtained [330]. Finally, there are commercial products for efficient removal of arsenic and these include iron oxide nanoparticles and polymers and nanocrystalline titanium dioxide medium in the form of beads [331, 332].

3.4. Removal of Organic Contaminants. NOM constitutes a diverse group of hydrophobic (humic and fulvic acids) and hydrophilic organic compounds and it contributes significantly towards water contamination [333-339]. A variety of carbon-based adsorbents have been used for the removal of NOM from raw water and several factors affect this sorption of NOM [340-343]. 
3.4.1. CNTs. Different types of nanomaterial like nanosorbents such as CNTs, polymeric materials (e.g., dendrimers), and zeolites have exceptional adsorption properties and are applied for removal of organics from water/wastewater [63]. CNTs have received special attention due to their exceptional water treatment capabilities and adsorption of organics on CNTs is widely studied and extensively reviewed [287]. The removal of NOM by CNTs is higher when compared with carbon-based adsorbents mainly due to large surface areas and other factors $[344,345]$. CNTs are also effective to remove polycyclic aromatic organic compounds [346-348] and atrazine [345].

Nanoporous activated carbon fibers, prepared by electrospinning of CNTs, showed much higher organic sorption equilibrium constants for benzene, toluene, xylene, and ethylbenzene than granular activated carbon [349]. The sorption of 1,2-dichlorobenzene by CNTs has been shown as effective in one study [350]. Compared with activated carbon, both single- and multiwalled CNTs displayed higher adsorption capacities for trihalomethanes [293, 351]. Multiwalled CNTs have been used as sorbents for chlorophenols, herbicides, DDTs, and so forth [352-355]. Finally, novel polymers with functionalized CNTs showed effective removal of organic pollutants from water [295].

3.4.2. $\mathrm{TiO}_{2}$ Nanoparticles. Metal oxide nanomaterials such as $\mathrm{TiO}_{2}$ in addition to $\mathrm{CeO}_{2}$ have also been used as catalysts for fast and comparatively complete degradation of organic pollutants in ozonation processes $[356,357]$. Photocatalysts like $\mathrm{TiO}_{2}$ nanoparticles are used effectively for the treatment of water contaminated with organic pollutants like polychlorinated biphenyls (PCBs), benzenes, and chlorinated alkanes [299]. Removal of total organic carbon from wastewater was enhanced by the addition of $\mathrm{TiO}_{2}$ nanoparticles in a study [358]. $\mathrm{TiO}_{2}$ nanoparticles were also used in a "falling film" reactor for the degradation of microcystins in water [159]. Multiwalled CNTs functionalized with Fe nanoparticles have been proved effective sorbents for aromatic compounds like benzene and toluene [359].

Decomposition of organic compounds can be enhanced by noble metal doping into $\mathrm{TiO}_{2}$ due to enhanced hydroxyl radical production and so forth [360-362]. For example, the doping $\mathrm{Si}$ into $\mathrm{TiO}_{2}$ nanoparticles was effective to improve its efficiency due to the increase in surface area and crystallinity $[363,364] . \mathrm{TiO}_{2}$ nanocrystals modified with noble metal deposits and so forth were used for the degradation of methylene blue in the visible-light range [198, $365,366]$. Nitrogen- and $\mathrm{Fe}(\mathrm{III}-)$ doped $\mathrm{TiO}_{2}$ nanoparticles were better in degrading azo dyes and phenol, respectively, than commercially available $\mathrm{TiO}_{2}$ nanoparticles $[367,368]$. $\mathrm{TiO}_{2}$ nanoparticles deposited onto porous $\mathrm{Al}_{2} \mathrm{O}_{3}$ were used effectively for the removal of TOC in a study [369]. $\mathrm{TiO}_{2}$ nanocomposites with mesoporous silica were also used for the treatment of aromatic pollutants [370-373]. A composite of nanosized $\mathrm{SO}_{4}{ }^{2-} / \mathrm{TiO}_{2}$ was used for the degradation of 4nitrophenol in one study [374]. $\mathrm{TiO}_{2}$ nanotubes have been used effectively to degrade toluene better than bulk structural materials [375] and were found to be more efficient than
$\mathrm{TiO}_{2}$ nanoparticles for degrading organic compounds [376]. A commercial product (Purifics Photo-Cat system) has been shown highly efficient at removing organics [377-379].

3.4.3. Zero-Valent Iron. Nanocatalysts including semiconductor materials, zero-valence metal, and bimetallic nanoparticles have been used for degradation of environmental contaminants such as PCBs, pesticides, and azo dyes due to their higher surface area and shape dependent properties [380]. Magnetic nanosorbents also have proved effective in organic contaminants removal [381]. Iron oxide nanomaterials have shown better removal capabilities of organic pollutants than bulk materials $[303,382,383] . \mathrm{Fe}_{2} \mathrm{O}_{3}$ nanoparticles have also been used for the removal of colored humic acids from wastewater [384]. Chlorinated organic compounds and PCBs have been transformed successfully using nZVI [385387] as well as inorganic ions such as nitrate and perchlorate $[388,389]$.

Particles of nZVI have been proved effective in degradation of toxic chlorinated organic compounds, for example, $2,2^{\prime}$-dichlorobiphenyl in a few remediation studies [390, 391]. The stabilized nZVI particles could also be an effective way for in situ remediation of groundwater or industrial effluents [392]. The nZVI and bimetallic nZVI have emerged as effective redox media for reducing a variety of organic pollutants such as PCBs, pesticides, organic dyes, chlorinated alkanes, and alkenes and inorganic anions (e.g., nitrates) in water/wastewater due to larger surface areas and reactivity $[393,394]$. Bimetallic $\mathrm{Ni}^{0} / \mathrm{Fe}^{0}$ and $\mathrm{Pd}^{0} / \mathrm{Fe}^{0}$ nanoparticles were more effective than commercial microscale $\mathrm{Fe}$ for reductive dehalogenation of chlorinated organics and brominated methanes, hydrodechlorination of chlorinated aliphatics, chlorinated aromatics, and PCBs as reported by many researchers [395-402].

3.4.4. Other Nanomaterials. In a study, nanostructured $\mathrm{ZnO}$ semiconductor films were used for degradation of organic contaminants (4-chlorocatechol) [403]. The nanocatalyst of $\mathrm{Ag}$ and amidoxime fibers was used efficiently for degradation of organic dyes [404]. A bimetallic nanocomposite of Pd$\mathrm{Cu} / \gamma$-alumina was used for the reduction of nitrate in one study [405]. Traces of halogenated organic compounds were biodegraded using hydrogen and the Pd based nanoparticles [301, 406]. Pd nanoparticles and bimetallic Pd/Au (gold) nanoparticles were used effectively for hydrodechlorination of trichloroethylene (TCE) [407, 408]. Mineralization of organic dyes was accelerated in one study by using films of manganese oxide $\left(\mathrm{MnO}_{2}\right)$ nanoparticles and hydrogen peroxide [409]. Similarly, $\mathrm{MnO}_{2}$ hierarchical hollow nanostructures were used for the removal of organic pollutant in waste water [410]. The immobilized nanoparticles of metallo-porphyrinogens have also been successfully used for the reductive dehalogenation of chlorinated organic compounds (TCE and carbon tetrachloride) [411]. The applicability of self-assembled monolayers on mesoporous supports for removing anions and radionuclides was also evaluated by many researchers [412, 413]. Molecularly imprinted nanospheres were used for the removal of micropollutants 
from hospital waste water [414]. Finally, single-enzyme nanoparticles could be used for decontaminating a broad range of organic contaminants as highlighted in one study [415].

3.4.5. Membranes. The immobilization of metallic nanoparticles in membrane has also been proved effective for degradation and dechlorination of toxic contaminants [416]. Inorganic membranes containing nano- $\mathrm{TiO}_{2}$ or modified nano$\mathrm{TiO}_{2}$ have been used effectively for reductive degradation of contaminants, particularly chlorinated compounds [417, 418]. The use of $\mathrm{TiO}_{2}$ immobilized on a polyethylene support and $\mathrm{TiO}_{2}$ slurry in combination with polymeric membranes has proved very effective in degrading 1,2-dichlorobenzene and pharmaceuticals, respectively $[419,420]$.

Polyethersulfone composite membranes with nano- $\mathrm{TiO}_{2}$ as additive showed higher fluxes and enhanced antifouling properties [421-423]. Ceramic composite membrane made of $\mathrm{TiO}_{2}$ nanoparticles inside a tubular $\mathrm{Al}_{2} \mathrm{O}_{3}$ substrate showed improved water quality and flux compared to $\mathrm{Al}_{2} \mathrm{O}_{3}$ membranes [424]. By doping $\mathrm{TiO}_{2}$ nanoparticles to the $\mathrm{Al}_{2} \mathrm{O}_{3}$ membrane, it was possible to control the membrane fouling by decreased adsorption of oil droplets to membrane surface in the treatment of oily wastewater [425]. Nanostructured composite of $\mathrm{TiO}_{2}$ and $\mathrm{Fe}_{2} \mathrm{O}_{3}$ incorporated into ultrafiltration membranes successfully reduced the fouling burden and improved the permeate flux [369].

Cellulose acetate membrane laden with nZVI was found effective in dechlorination of TCE [426]. A reactive membrane of bimetallic $\mathrm{nZVI}$ and $\mathrm{Pt}^{0}$ nanoparticles was found to be very effective at reducing TCE [427]. Bimetallic Fe/Ni and $\mathrm{Fe} / \mathrm{Pd}$ nanoparticles incorporated in nZVI as polymerinorganic porous composite membranes have been successfully used for the reductive degradation of halogenated organic solvents [428-430]. Polyvinylidene fluoride film containing $\mathrm{Pd}$ and $\mathrm{Pd} / \mathrm{Fe}$ was used effectively for dechlorination of PCB's in one study [431] leading to the development of a membrane reactor for dechlorination of a wider range of compounds [391, 432]. Alumina-zirconia-titania ceramic membrane coated with $\mathrm{Fe}_{2} \mathrm{O}_{3}$ nanoparticles was observed to reduce the dissolved organic carbon better than the uncoated membrane enhancing the degradation of NOM $[273,433]$. Finally, ceramic composite membranes of $\mathrm{TiO}_{2}$ and CNTs have resulted in enhanced membrane permeability and photocatalytic activity [434-436].

$\mathrm{NF}$ is reviewed for the removal of NOM and nitrates from ground/surface waters [326] and it has been reported to improve the water quality with a substantial reduction in organic contaminants [437]. Cost-effective nanostructured and reactive membranes are fabricated using different nanomaterials to develop more efficient water purification methods and in a study ceramic membrane of $\mathrm{Al}_{2} \mathrm{O}_{3}$ nanoparticles alone and doped with $\mathrm{Fe}, \mathrm{Mn}$, and La showed selectivity towards three different synthetic dyes [84]. An improved antifouling performance and flux increase was also observed in silica-incorporated membranes [438].

In the context of improving the UF processes for water treatment containing organic and inorganic solutes, dendritic polymers are used as water-soluble ligands for radionuclides and inorganic anions $[439,440]$. Nearly complete reduction of 4-nitrophenol was seen when using a composite membrane composed of alumina and polymers through layerby-layer adsorption of polyelectrolytes and citrate-stabilized Au nanoparticles [89]. Finally, the addition of metal oxide nanoparticles including silica, $\mathrm{TiO}_{2}$, alumina, and zeolites to polymeric ultrafiltration membranes has helped reducing fouling [441-445].

\section{Conclusions and Perspectives}

Safe water has become a competitive resource in many parts of the world due to increasing population, prolonged droughts, climate change, and so forth. Nanomaterials have unique characteristics, for example, large surface areas, size, shape, and dimensions, that make them particularly attractive for water/wastewater treatment applications such as disinfection, adsorption, and membrane separations. The review of the literature has shown that water/wastewater treatment using nanomaterials is a promising field for current and future research.

Surface modifications of different nanomaterials like nanoscale $\mathrm{TiO}_{2}$, nZVI by coupling with a second catalytic metal can result in enhanced water/wastewater quality when applied for this purpose by increasing the selectivity and reactivity of the selected materials. Surface modification may lead to the enhanced photocatalytic activity of the selected compounds due to the short lifetime of reactive oxygen species and increase the affinity of modified nanomaterials towards many emerging water contaminants. Bimetallic nanoparticles have also proved effective for remediation of water contaminants. However, further studies are required for understanding the mechanism of degradation on bimetallic nanoparticles responsible for the improved efficiency. For real field applications, however, an improved understanding of the process mechanism is very important for the successful applications of innovative nanocomposites for water/wastewater treatment.

Electrospinning offers the way to modify the surface properties of nanomaterials and different nanofibrous filters have successfully been used as antifouling water filtration membranes. They have extremely high surface-tovolume ratio and porosity, are very active against waterborne pathogens, less toxic with minimum health risks, and provide solutions to ensure safe water. It is very easy to dope functional nanomaterials to form multifunctional media/membrane filters with increased reactivity and selectivity for different contaminants. Although these electrospun nanofibers are prepared by simple and cost-effective method, their manufacturing at industrial scale is still a challenge and it is vital to consider the subject from an engineering aspect. The use of nanofibrous composites membranes for water/wastewater treatment is very limited and a stand-alone system (Figure 3 ) is proposed for removing all types of contaminants including bacteria/viruses, heavy metals and ions, and complex organic compounds. 


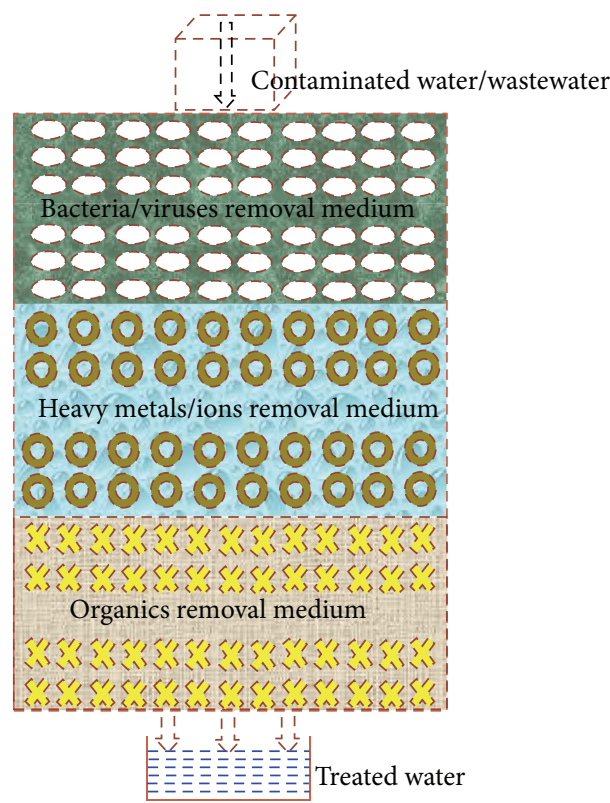

FIGURE 3: Schematic of a proposed composite nanofibrous media/membrane filters for complete removal of contaminants from water/wastewater.

The use of nanofibers and composite nanostructures membranes can help degrade a wide range of organic and inorganic contaminants in real field applications. The better understanding of the formation of nanocomposites membranes will certainly be a step towards improving the performance of multifunctional nanocomposites membranes. The pattern of nanoparticles within the host matrices of membranes and changes in the structures and properties of both nanomaterials and host matrices could be among the priority concerns in the real field applications of the nanofibrous membranes for water/wastewater treatment.

\section{Conflict of Interests}

The authors declare that there is no conflict of interests regarding the publication of this paper.

\section{Acknowledgment}

This project was supported by the NSTIP strategic technologies program, Grant no. 11-WAT1875-02, Kingdom of Saudi Arabia.

\section{References}

[1] D. D. Mara, "Water, sanitation and hygiene for the health of developing nations," Public Health, vol. 117, no. 6, pp. 452-456, 2003.

[2] M. Moore, P. Gould, and B. S. Keary, "Global urbanization and impact on health," International Journal of Hygiene and Environmental Health, vol. 206, no. 4-5, pp. 269-278, 2003.

[3] D. M. Johnson, D. R. Hokanson, Q. Zhang, K. D. Czupinski, and J. Tang, "Feasibility of water purification technology in rural areas of developing countries," Journal of Environmental Management, vol. 88, no. 3, pp. 416-427, 2008.

[4] M. A. Montgomery and M. Elimelech, "Water and sanitation in developing countries: Including health in the equation," Environmental Science and Technology, vol. 41, no. 1, pp. 17-24, 2007.

[5] J. Theron and T. E. Cloete, "Emerging waterborne infections: contributing factors, agents, and detection tools," Critical Reviews in Microbiology, vol. 28, no. 1, pp. 1-26, 2002.

[6] K. Eshelby, "Dying for a drink," British Medical Journal, vol. 334, no. 7594, pp. 610-612, 2007.

[7] P. Leonard, S. Hearty, J. Brennan et al., "Advances in biosensors for detection of pathogens in food and water," Enzyme and Microbial Technology, vol. 32, no. 1, pp. 3-13, 2003.

[8] N. J. Ashbolt, "Microbial contamination of drinking water and disease outcomes in developing regions," Toxicology, vol. 198, no. 1-3, pp. 229-238, 2004.

[9] G. Hutton, L. Haller, and J. Bartram, Economic and Health Effects of Increasing Coverage of Low Cost Household Drinking Water Supply and Sanitation Interventions, World Health Organization, 2007.

[10] World Health Organization and UNICEF, Progress on Sanitation and Drinking-Water, World Health Organization, Geneva, Switzerland, 2013.

[11] M. I. L'vovich, World Water Resources and Their Future, American Geophysical Union, Washington, DC, USA, 1979.

[12] S. L. Postel, G. C. Daily, and P. R. Ehrlich, "Human appropriation of renewable fresh water," Science, vol. 271, no. 5250, pp. 785-788, 1996.

[13] P. H. Gleick, P. I. for S. in D., Environment, and Security, and S. E. Institute, Water in Crisis: A Guide to the World's Fresh Water Resources, Oxford University Press, 1993.

[14] I. A. Shiklomanov, "Appraisal and assessment of world water resources," Water International, vol. 25, no. 1, pp. 11-32, 2000.

[15] J. Rockström, "Water for food and nature in drought-prone tropics: vapour shift in rain-fed agriculture," Philosophical Transactions of the Royal Society B: Biological Sciences, vol. 358, no. 1440, pp. 1997-2009, 2003.

[16] D. Seckler, D. Molden, and R. Sakthivadivel, The Concept of Efficiency in Water Resources Management and Policy, 2003.

[17] H. El-Dessouky and H. Ettouney, "Teaching desalination-a multidiscipline engineering science," Heat Transfer Engineering, vol. 23, no. 5, pp. 1-3, 2002.

[18] C. J. Vörösmarty, P. Green, J. Salisbury, and R. B. Lammers, "Global water resources: Vulnerability from climate change and population growth," Science, vol. 289, no. 5477, pp. 284-288, 2000.

[19] M. A. Shannon, P. W. Bohn, M. Elimelech, J. G. Georgiadis, B. J. Marĩas, and A. M. Mayes, "Science and technology for water purification in the coming decades," Nature, vol. 452, no. 7185, pp. 301-310, 2008.

[20] H. C. J. Godfray, J. R. Beddington, I. R. Crute et al., "Food security: the challenge of feeding 9 billion people," Science, vol. 327, no. 5967, pp. 812-818, 2010.

[21] K. Mulder, N. Hagens, and B. Fisher, "Burning water: a comparative analysis of the energy return on water invested," Ambio, vol. 39, no. 1, pp. 30-39, 2010.

[22] K. E. Kemper, "Groundwater-from development to management," Hydrogeology Journal, vol. 12, no. 1, pp. 3-5, 2004.

[23] J. A. Foley, R. DeFries, G. P. Asner et al., "Global consequences of land use," Science, vol. 309, no. 5734, pp. 570-574, 2005. 
[24] S. E. Coetser, R. G. M. Heath, and N. Ndombe, "Diffuse pollution associated with the mining sectors in South Africa: a first-order assessment," Water Science and Technology, vol. 55, no. 3, pp. 9-16, 2007.

[25] L. Ritter, K. Solomon, P. Sibley et al., "Sources, pathways, and relative risks of contaminants in surface water and groundwater: a perspective prepared for the Walkerton inquiry," Journal of Toxicology and Environmental Health-Part A, vol. 65, no. 1, pp. 1-142, 2002.

[26] J. Fawell and M. J. Nieuwenhuijsen, "Contaminants in drinking water," British Medical Bulletin, vol. 68, pp. 199-208, 2003.

[27] S. Rodriguez-Mozaz, M. J. López De Alda, and D. Barceló, "Monitoring of estrogens, pesticides and bisphenol A in natural waters and drinking water treatment plants by solid-phase extraction-liquid chromatography-mass spectrometry," Journal of Chromatography A, vol. 1045, no. 1-2, pp. 85-92, 2004.

[28] I. R. Falconer and A. R. Humpage, "Health risk assessment of cyanobacterial (blue-green algal) toxins in drinking water," International Journal of Environmental Research and Public Health, vol. 2, no. 1, pp. 43-50, 2005.

[29] J. C. Bowman, J. L. Zhou, and J. W. Readman, "Sediment-water interactions of natural oestrogens under estuarine conditions," Marine Chemistry, vol. 77, no. 4, pp. 263-276, 2002.

[30] I. M. Verstraeten, T. Heberer, J. R. Vogel, T. Speth, S. Zuehlke, and U. Duennbier, "Occurrence of endocrine-disrupting and other wastewater compunds during water treatment with case studies from Lincoln, Nebraska and Berlin, Germany," Practice Periodical of Hazardous, Toxic, and Radioactive Waste Management, vol. 7, no. 4, pp. 253-263, 2003.

[31] H. Ozaki, "Rejection of micropollutants by membrane filtration," in Proceedings of the Regional Symposium on Membrane Science and Technology, Johor, Malaysia, 2004.

[32] M. R. Servos, D. T. Bennie, B. K. Burnison et al., "Distribution of estrogens, $17 \beta$-estradiol and estrone, in Canadian municipal wastewater treatment plants," Science of the Total Environment, vol. 336, no. 1-3, pp. 155-170, 2005.

[33] T. Urase and T. Kikuta, "Separate estimation of adsorption and degradation of pharmaceutical substances and estrogens in the activated sludge process," Water Research, vol. 39, no. 7, pp. 1289-1300, 2005.

[34] M. Petrovic, A. Diaz, F. Ventura, and D. Barceló, "Occurrence and removal of estrogenic short-chain ethoxy nonylphenolic compounds and their halogenated derivatives during drinking water production," Environmental Science and Technology, vol. 37, no. 19, pp. 4442-4448, 2003.

[35] P. Westerhoff, Y. Yoon, S. Snyder, and E. Wert, "Fate of endocrine-disruptor, pharmaceutical, and personal care product chemicals during simulated drinking water treatment processes," Environmental Science and Technology, vol. 39, no. 17, pp. 6649-6663, 2005.

[36] N. Vieno, T. Tuhkanen, and L. Kronberg, "Removal of pharmaceuticals in drinking water treatment: Effect of chemical coagulation," Environmental Technology, vol. 27, no. 2, pp. 183192, 2006.

[37] U. Szewzyk, R. Szewzyk, W. Manz, and K.-H. Schleifer, "Microbiogical safety of drinking water," Annual Review of Microbiology, vol. 54, pp. 81-127, 2000.

[38] W. Zhang and F. A. DiGiano, "Comparison of bacterial regrowth in distribution systems using free chlorine and chloramine: A statistical study of causative factors," Water Research, vol. 36, no. 6, pp. 1469-1482, 2002.
[39] I. H. Suffet, J. Ho, D. Chou, D. Khiari, and J. Mallevialle, "Tasteand- odor problems observed during drinking water treatment," in Advances in Taste-and-Odor Treatment and Control, I. H. Suffet, J. Mallevialle, and E. Kawczynski, Eds., American Water Works Association, 1995.

[40] G. Becher, "Drinking water chlorination and health," Acta Hydrochimica et Hydrobiologica, vol. 27, no. 2, pp. 100-102, 1999.

[41] R. M. Hozalski, L. Zhang, and W. A. Arnold, "Reduction of haloacetic acids by $\mathrm{Fe} 0$ : implications for treatment and fate," Environmental Science and Technology, vol. 35, no. 11, pp. 22582263, 2001.

[42] R. Sadiq and M. J. Rodriguez, "Disinfection by-products (DBPs) in drinking water and predictive models for their occurrence: a review," Science of the Total Environment, vol. 321, no. 1-3, pp. 21-46, 2004.

[43] K. Gopal, S. S. Tripathy, J. L. Bersillon, and S. P. Dubey, "Chlorination byproducts, their toxicodynamics and removal from drinking water," Journal of Hazardous Materials, vol. 140, no. 1-2, pp. 1-6, 2007.

[44] C. Adams, Y. Wang, K. Loftin, and M. Meyer, "Removal of antibiotics from surface and distilled water in conventional water treatment processes," Journal of Environmental Engineering, vol. 128, no. 3, pp. 253-260, 2002.

[45] H. Strathmann, "Membrane separation processes: current relevance and future opportunities," AIChE Journal, vol. 47, no. 5, pp. 1077-1087, 2001.

[46] B. Van der Bruggen and C. Vandecasteele, "Distillation vs. membrane filtration: overview of process evolutions in seawater desalination," Desalination, vol. 143, no. 3, pp. 207-218, 2002.

[47] A. L. Ahmad, B. S. Ooi, A. W. Mohammad, and J. P. Choudhury, "Development of a highly hydrophilic nanofiltration membrane for desalination and water treatment," Desalination, vol. 168, no. 1-3, pp. 215-221, 2004.

[48] J.-J. Qin, M. H. Oo, and K. A. Kekre, "Nanofiltration for recovering wastewater from a specific dyeing facility," Separation and Purification Technology, vol. 56, no. 2, pp. 199-203, 2007.

[49] K. Walha, R. B. Amar, L. Firdaous, F. Quéméneur, and P. Jaouen, "Brackish groundwater treatment by nanofiltration, reverse osmosis and electrodialysis in Tunisia: performance and cost comparison," Desalination, vol. 207, no. 1-3, pp. 95-106, 2007.

[50] M. Mulder, "The use of membrane processes in environmental problems. An introduction," in Membrane Processes in Separation and Purification, J. G. Crespo and K. W. Böddeker, Eds., pp. 229-262, Springer, 1994.

[51] Y. Kiso, T. Kon, T. Kitao, and K. Nishimura, "Rejection properties of alkyl phthalates with nanofiltration membranes," Journal of Membrane Science, vol. 182, no. 1-2, pp. 205-214, 2001.

[52] M. Bodzek, M. Dudziak, and K. Luks-Betlej, "Application of membrane techniques to water purification. Removal of phthalates," Desalination, vol. 162, no. 1-3, pp. 121-128, 2004.

[53] G. Owen, M. Bandi, J. A. Howell, and S. J. Churchouse, "Economic assessment of membrane processes for water and waste water treatment," Journal of Membrane Science, vol. 102, no. 1-3, pp. 77-91, 1995.

[54] Y. Yoon, P. Westerhoff, J. Yoon, and S. A. Snyder, "Removal of $17 \beta$ estradiol and fluoranthene by nanofiltration and ultrafiltration," Journal of Environmental Engineering, vol. 130, no. 12, pp. 1460-1467, 2004.

[55] Y. Yoon, P. Westerhoff, S. A. Snyder, and E. C. Wert, "Nanofiltration and ultrafiltration of endocrine disrupting compounds, pharmaceuticals and personal care products," Journal of Membrane Science, vol. 270, no. 1-2, pp. 88-100, 2006. 
[56] L. Braeken, B. Bettens, K. Boussu et al., “Transport mechanisms of dissolved organic compounds in aqueous solution during nanofiltration," Journal of Membrane Science, vol. 279, no. 1-2, pp. 311-319, 2006.

[57] N. Bolong, A. F. Ismail, M. R. Salim, and T. Matsuura, "A review of the effects of emerging contaminants in wastewater and options for their removal," Desalination, vol. 238, no. 1-3, pp. 229-246, 2009.

[58] J.-Y. Bottero, J. Rose, and M. R. Wiesner, "Nanotechnologies: tools for sustainability in a new wave of water treatment processes," Integrated Environmental Assessment and Management, vol. 2, no. 4, pp. 391-395, 2006.

[59] S. O. Obare and G. J. Meyer, "Nanostructured materials for environmental remediation of organic contaminants in water," Journal of Environmental Science and Health-Part A, vol. 39, no. 10, pp. 2549-2582, 2004.

[60] E. J. Lee and K. J. Schwab, "Deficiencies in drinking water distribution systems in developing countries," Journal of Water and Health, vol. 3, no. 2, pp. 109-127, 2005.

[61] C. L. Moe and R. D. Rheingans, "Global challenges in water, sanitation and health," Journal of Water and Health, vol. 4, no. 1, pp. 41-58, 2006.

[62] W. J. Weber Jr., "Distributed optimal technology networks: a concept and strategy for potable water sustainability," Water Science and Technology, vol. 46, no. 6-7, pp. 241-246, 2002.

[63] N. Savage and M. S. Diallo, "Nanomaterials and water purification: opportunities and challenges," Journal of Nanoparticle Research, vol. 7, no. 4-5, pp. 331-342, 2005.

[64] T. Masciangioli and W. X. Zhang, "Peer reviewed: environmental technologies at the nanoscale," Environmental Science \& Technology, vol. 37, no. 5, pp. 102A-108A, 2003.

[65] J. C. T. Eijkel and A. van den Berg, "Nanofluidics: what is it and what can we expect from it?" Microfluidics and Nanofluidics, vol. 1, no. 3, pp. 249-267, 2005.

[66] D. G. Rickerby and M. Morrison, "Nanotechnology and the environment: a European perspective," Science and Technology of Advanced Materials, vol. 8, no. 1-2, pp. 19-24, 2007.

[67] A. Vaseashta, M. Vaclavikova, S. Vaseashta, G. Gallios, P. Roy, and O. Pummakarnchana, "Nanostructures in environmental pollution detection, monitoring, and remediation," Science and Technology of Advanced Materials, vol. 8, no. 1-2, pp. 47-59, 2007.

[68] X. Qu, P. J. J. Alvarez, and Q. Li, "Applications of nanotechnology in water and wastewater treatment," Water Research, vol. 47, no. 12, pp. 3931-3946, 2013.

[69] P. Gautam, D. Madathil, and A. N. Brijesh Nair, "Nanotechnology in waste water treatment: a review," International Journal of ChemTech Research, vol. 5, no. 5, pp. 2303-2308, 2013.

[70] J. Riu, A. Maroto, and F. X. Rius, "Nanosensors in environmental analysis," Talanta, vol. 69, no. 2, pp. 288-301, 2006.

[71] J. Theron, J. A. Walker, and T. E. Cloete, "Nanotechnology and water treatment: applications and emerging opportunities," Critical Reviews in Microbiology, vol. 34, no. 1, pp. 43-69, 2008.

[72] A. P. Alivisatos, "Perspectives on the physical chemistry of semiconductor nanocrystals," The Journal of Physical Chemistry, vol. 100, no. 31, pp. 13226-13239, 1996.

[73] A. P. Alivisatos, "Semiconductor clusters, nanocrystals, and quantum dots," Science, vol. 271, no. 5251, pp. 933-937, 1996.

[74] J. Z. Zhang, "Ultrafast studies of electron dynamics in semiconductor and metal colloidal nanoparticles: effects of size and surface," Accounts of Chemical Research, vol. 30, no. 10, pp. 423429, 1997.
[75] S. V. Gaponenko, Optical Properties of Semiconductor Nanocrystals, Cambridge University Press, Cambridge, UK, 1998.

[76] S. J. Rosenthal, "Bar-coding biomolecules with fluorescent nanocrystals," Nature Biotechnology, vol. 19, no. 7, pp. 621-622, 2001.

[77] R. A. Crane and T. B. Scott, "Nanoscale zero-valent iron: future prospects for an emerging water treatment technology," Journal of Hazardous Materials, vol. 211-212, pp. 112-125, 2012.

[78] J. Fei and J. Li, "Metal oxide nanomaterials for water treatment," in Nanotechnologies for the Life Sciences, Wiley-VCH Verlag $\mathrm{GmbH} \& \mathrm{Co} . \mathrm{KGaA}, 2007$.

[79] U. Manzoor, M. Islam, L. Tabassam, and S. U. Rahman, "Quantum confinement effect in $\mathrm{ZnO}$ nanoparticles synthesized by co-precipitate method," Physica E, vol. 41, no. 9, pp. 1669-1672, 2009.

[80] S. Zia, M. Amin, U. Manzoor, and A. S. Bhatti, "Ultra-long multicolor belts and unique morphologies of tin-doped zinc oxide nanostructures," Applied Physics A: Materials Science and Processing, vol. 115, no. 1, pp. 275-281, 2014.

[81] D. Bhattacharyya, J. A. Hestekin, P. Brushaber, L. Cullen, L. G. Bachas, and S. K. Sikdar, "Novel poly-glutamic acid functionalized microfiltration membranes for sorption of heavy metals at high capacity," Journal of Membrane Science, vol. 141, no. 1, pp. 121-135, 1998.

[82] S. M. C. Ritchie, L. G. Bachas, T. Olin, S. K. Sikdar, and D. Bhattacharyya, "Surface modification of silica- and cellulosebased microfiltration membranes with functional polyamino acids for heavy metal sorption," Langmuir, vol. 15, no. 19, pp. 6346-6357, 1999.

[83] S. M. C. Ritchie, K. E. Kissick, L. G. Bachas, S. K. Sikdar, C. Parikh, and D. Bhattacharyya, "Polycysteine and other polyamino acid functionalized microfiltration membranes for heavy metal capture," Environmental Science and Technology, vol. 35, no. 15, pp. 3252-3258, 2001.

[84] K. A. DeFriend, M. R. Wiesner, and A. R. Barron, "Alumina and aluminate ultrafiltration membranes derived from alumina nanoparticles," Journal of Membrane Science, vol. 224, no. 1-2, pp. 11-28, 2003.

[85] B. W. Stanton, J. J. Harris, M. D. Miller, and M. L. Bruening, "Ultrathin, multilayered polyelectrolyte films as nanofiltration membranes," Langmuir, vol. 19, no. 17, pp. 7038-7042, 2003.

[86] A. M. Hollman and D. Bhattacharyya, "Pore assembled multilayers of charged polypeptides in microporous membranes for ion separation," Langmuir, vol. 20, no. 13, pp. 5418-5424, 2004.

[87] A. N. Chatterjee, D. M. Cannon Jr., E. N. Gatimu, J. V. Sweedler, N. R. Aluru, and P. W. Bohn, "Modeling and simulation of ionic currents in three-dimensional microfluidic devices with nanofluidic interconnects," Journal of Nanoparticle Research, vol. 7, no. 4-5, pp. 507-516, 2005.

[88] J. Xu, A. Dozier, and D. Bhattacharyya, "Synthesis of nanoscale bimetallic particles in polyelectrolyte membrane matrix for reductive transformation of halogenated organic compounds," Journal of Nanoparticle Research, vol. 7, no. 4-5, pp. 449-467, 2005.

[89] D. M. Dotzauer, J. Dai, L. Sun, and M. L. Bruening, "Catalytic membranes prepared using layer-by-layer adsorption of polyelectrolyte/metal nanoparticle films in porous supports," Nano Letters, vol. 6, no. 10, pp. 2268-2272, 2006.

[90] M. Arkas, R. Allabashi, D. Tsiourvas, E.-M. Mattausch, and R. Perfler, "Organic/inorganic hybrid filters based on dendritic and cyclodextrin "nanosponges" for the removal of organic 
pollutants from water," Environmental Science and Technology, vol. 40, no. 8, pp. 2771-2777, 2006.

[91] R. Allabashi, M. Arkas, G. Hörmann, and D. Tsiourvas, "Removal of some organic pollutants in water employing ceramic membranes impregnated with cross-linked silylated dendritic and cyclodextrin polymers," Water Research, vol. 41, no. 2, pp. 476-486, 2007.

[92] M. M. Cortalezzi, J. Rose, G. F. Wells, J.-Y. Bottero, A. R. Barron, and M. R. Wiesner, "Ceramic membranes derived from ferroxane nanoparticles: a new route for the fabrication of iron oxide ultrafiltration membranes," Journal of Membrane Science, vol. 227, no. 1-2, pp. 207-217, 2003.

[93] J.-F. Li, Z.-L. Xu, H. Yang, L.-Y. Yu, and M. Liu, "Effect of $\mathrm{TiO}_{2}$ nanoparticles on the surface morphology and performance of microporous PES membrane," Applied Surface Science, vol. 255, no. 9, pp. 4725-4732, 2009.

[94] A. Bottino, G. Capannelli, and A. Comite, "Preparation and characterization of novel porous PVDF-ZrO2 composite membranes," Desalination, vol. 146, no. 1-3, pp. 35-40, 2002.

[95] S. H. Kim, S.-Y. Kwak, B.-H. Sohn, and T. H. Park, "Design of $\mathrm{TiO}_{2}$ nanoparticle self-assembled aromatic polyamide thinfilm-composite (TFC) membrane as an approach to solve biofouling problem," Journal of Membrane Science, vol. 211, no. 1, pp. 157-165, 2003.

[96] J.-H. Li, Y.-Y. Xu, L.-P. Zhu, J.-H. Wang, and C.-H. Du, "Fabrication and characterization of a novel $\mathrm{TiO}_{2}$ nanoparticle self-assembly membrane with improved fouling resistance," Journal of Membrane Science, vol. 326, no. 2, pp. 659-666, 2009.

[97] J. Kim, S. H. R. Davies, M. J. Baumann, V. V. Tarabara, and S. J. Masten, "Effect of ozone dosage and hydrodynamic conditions on the permeate flux in a hybrid ozonation-ceramic ultrafiltration system treating natural waters," Journal of Membrane Science, vol. 311, no. 1-2, pp. 165-172, 2008.

[98] S.-R. Chae, S. Wang, Z. D. Hendren, M. R. Wiesner, Y. Watanabe, and C. K. Gunsch, "Effects of fullerene nanoparticles on Escherichia coli K12 respiratory activity in aqueous suspension and potential use for membrane biofouling control," Journal of Membrane Science, vol. 329, no. 1-2, pp. 68-74, 2009.

[99] R. S. Barhate and S. Ramakrishna, "Nanofibrous filtering media: filtration problems and solutions from tiny materials," Journal of Membrane Science, vol. 296, no. 1-2, pp. 1-8, 2007.

[100] A. Frenot and I. S. Chronakis, "Polymer nanofibers assembled by electrospinning," Current Opinion in Colloid and Interface Science, vol. 8, no. 1-2, pp. 64-75, 2003.

[101] I. C. Escobar, A. A. Randall, and J. S. Taylor, "Bacterial growth in distribution systems: effect of assimilable organic carbon and biodegradable dissolved organic carbon," Environmental Science and Technology, vol. 35, no. 17, pp. 3442-3447, 2001.

[102] I. Majsterek, P. Sicinska, M. Tarczynska, M. Zalewski, and Z. Walter, "Toxicity of microcystin from cyanobacteria growing in a source of drinking water," Comparative Biochemistry and Physiology -C Toxicology and Pharmacology, vol. 139, no. 1-3, pp. 175-179, 2004.

[103] D. Berry, C. Xi, and L. Raskin, "Microbial ecology of drinking water distribution systems," Current Opinion in Biotechnology, vol. 17, no. 3, pp. 297-302, 2006.

[104] N. R. Dugan and D. J. Williams, "Cyanobacteria passage through drinking water filters during perturbation episodes as a function of cell morphology, coagulant and initial filter loading rate," Harmful Algae, vol. 5, no. 1, pp. 26-35, 2006.

[105] S. Srinivasan, G. W. Harrington, I. Xagoraraki, and R. Goel, "Factors affecting bulk to total bacteria ratio in drinking water distribution systems," Water Research, vol. 42, no. 13, pp. 33933404, 2008.

[106] W.-J. Huang, B.-L. Cheng, and Y.-L. Cheng, "Adsorption of microcystin-LR by three types of activated carbon," Journal of Hazardous Materials, vol. 141, no. 1, pp. 115-122, 2007.

[107] F. Al Momani, D. W. Smith, and M. Gamal El-Din, "Degradation of cyanobacteria toxin by advanced oxidation processes," Journal of Hazardous Materials, vol. 150, no. 2, pp. 238-249, 2008.

[108] P. Pendleton, R. Schumann, and S. H. Wong, "Microcystin-LR adsorption by activated carbon," Journal of Colloid and Interface Science, vol. 240, no. 1, pp. 1-8, 2001.

[109] D.-K. Lee, S.-C. Kim, I.-C. Cho, S.-J. Kim, and S.-W. Kim, "Photocatalytic oxidation of microcystin-LR in a fluidized bed reactor having $\mathrm{TiO}_{2}$-coated activated carbon," Separation and Purification Technology, vol. 34, no. 1-3, pp. 59-66, 2004.

[110] H. Yan, A. Gong, H. He, J. Zhou, Y. Wei, and L. Lv, "Adsorption of microcystins by carbon nanotubes," Chemosphere, vol. 62, no. 1, pp. 142-148, 2006.

[111] H. Wang, L. Ho, D. M. Lewis, J. D. Brookes, and G. Newcombe, "Discriminating and assessing adsorption and biodegradation removal mechanisms during granular activated carbon filtration of microcystin toxins," Water Research, vol. 41, no. 18, pp. 4262-4270, 2007.

[112] P. Jain and T. Pradeep, "Potential of silver nanoparticle-coated polyurethane foam as an antibacterial water filter," Biotechnology and Bioengineering, vol. 90, no. 1, pp. 59-63, 2005.

[113] J. A. Spadaro, T. J. Berger, S. D. Barranco, S. E. Chapin, and R. O. Becker, "Antibacterial effects of silver electrodes with weak direct current," Antimicrobial agents and chemotherapy, vol. 6, no. 5, pp. 637-642, 1974.

[114] G. Zhao and S. E. Stevens Jr., "Multiple parameters for the comprehensive evaluation of the susceptibility of Escherichia coli to the silver ion," BioMetals, vol. 11, no. 1, pp. 27-32, 1998.

[115] Y. Inoue, M. Hoshino, H. Takahashi et al., "Bactericidal activity of Ag-zeolite mediated by reactive oxygen species under aerated conditions," Journal of Inorganic Biochemistry, vol. 92, no. 1, pp. 37-42, 2002.

[116] V.S. Kumar, B. M. Nagaraja, V. Shashikala et al., "Highly efficient $\mathrm{Ag} / \mathrm{C}$ catalyst prepared by electro-chemical deposition method in controlling microorganisms in water," Journal of Molecular Catalysis A: Chemical, vol. 223, no. 1-2, pp. 313-319, 2004.

[117] Q. L. Feng, J. Wu, G. Q. Chen, F. Z. Cui, T. N. Kim, and J. O. Kim, "A mechanistic study of the antibacterial effect of silver ions on Escherichia coli and Staphylococcus aureus," Journal of Biomedical Materials Research, vol. 52, no. 4, pp. 662-668, 2000.

[118] M. Yamanaka, K. Hara, and J. Kudo, "Bactericidal actions of a silver ion solution on Escherichia coli, studied by energyfiltering transmission electron microscopy and proteomic analysis," Applied and Environmental Microbiology, vol. 71, no. 11, pp. 7589-7593, 2005.

[119] I. Sondi and B. Salopek-Sondi, "Silver nanoparticles as antimicrobial agent: a case study on E. coli as a model for Gramnegative bacteria," Journal of Colloid and Interface Science, vol. 275, no. 1, pp. 177-182, 2004.

[120] C. Baker, A. Pradhan, L. Pakstis, D. J. Pochan, and S. I. Shah, "Synthesis and antibacterial properties of silver nanoparticles," Journal of Nanoscience and Nanotechnology, vol. 5, no. 2, pp. 244-249, 2005.

[121] A. Panáček, L. Kvítek, R. Prucek et al., "Silver colloid nanoparticles: synthesis, characterization, and their antibacterial activity," The Journal of Physical Chemistry B, vol. 110, no. 33, pp. 1624816253, 2006. 
[122] J. S. Kim, E. Kuk, K. N. Yu et al., "Antimicrobial effects of silver nanoparticles," Nanomedicine: Nanotechnology, Biology, and Medicine, vol. 3, no. 1, pp. 95-101, 2007.

[123] S. Shrivastava, T. Bera, A. Roy, G. Singh, P. Ramachandrarao, and D. Dash, "Characterization of enhanced antibacterial effects of novel silver nanoparticles," Nanotechnology, vol. 18, no. 22, Article ID 225103, 2007.

[124] J. R. Morones, J. L. Elechiguerra, A. Camacho et al., "The bactericidal effect of silver nanoparticles," Nanotechnology, vol. 16, no. 10, pp. 2346-2353, 2005.

[125] S. Makhluf, R. Dror, Y. Nitzan, Y. Abramovich, R. Jelinek, and A. Gedanken, "Microwave-assisted synthesis of nanocrystalline $\mathrm{MgO}$ and its use as a bacteriocide," Advanced Functional Materials, vol. 15, no. 10, pp. 1708-1715, 2005.

[126] S. Pal, Y. K. Tak, and J. M. Song, "Does the antibacterial activity of silver nanoparticles depend on the shape of the nanoparticle? A study of the gram-negative bacterium Escherichia coli," Applied and Environmental Microbiology, vol. 73, no. 6, pp. 17121720, 2007.

[127] Z.-M. Xiu, J. Ma, and P. J. J. Alvarez, "Differential effect of common ligands and molecular oxygen on antimicrobial activity of silver nanoparticles versus silver ions," Environmental Science and Technology, vol. 45, no. 20, pp. 9003-9008, 2011.

[128] Z.-M. Xiu, Q.-B. Zhang, H. L. Puppala, V. L. Colvin, and P. J. J. Alvarez, "Negligible particle-specific antibacterial activity of silver nanoparticles," Nano Letters, vol. 12, no. 8, pp. 4271-4275, 2012.

[129] S. Y. Liau, D. C. Read, W. J. Pugh, J. R. Furr, and A. D. Russell, "Interaction of silver nitrate with readily identifiable groups: relationship to the antibacterial action of silver ions," Letters in Applied Microbiology, vol. 25, no. 4, pp. 279-283, 1997.

[130] M. Danilczuk, A. Lund, J. Sadlo, H. Yamada, and J. Michalik, "Conduction electron spin resonance of small silver particles," Spectrochimica Acta-Part A: Molecular and Biomolecular Spectroscopy, vol. 63, no. 1, pp. 189-191, 2006.

[131] A. Esteban-Cubillo, C. Pecharromán, E. Aguilar, J. Santarén, and J. S. Moya, "Antibacterial activity of copper monodispersed nanoparticles into sepiolite," Journal of Materials Science, vol. 41, no. 16, pp. 5208-5212, 2006.

[132] W. K. Son, J. H. Youk, T. S. Lee, and W. H. Park, "Preparation of antimicrobial ultrafine cellulose acetate fibers with silver nanoparticles," Macromolecular Rapid Communications, vol. 25, no. 18, pp. 1632-1637, 2004.

[133] L. Balogh, D. R. Swanson, D. A. Tomalia, G. L. Hagnauer, and A. T. McManus, "Dendrimer-Silver Complexes and Nanocomposites as Antimicrobial Agents," Nano Letters, vol. 1, no. 1, pp. 18-21, 2001.

[134] Y. Chen, L. Wang, S. Jiang, and H. Yu, "Study on Novel Antibacterial Polymer Materials (I) Preparation of Zeolite Antibacterial Agents and Antibacterial Polymer Composite and Their Antibacterial Properties," Journal of Polymer Materials, vol. 20, no. 3, pp. 279-284, 2003.

[135] M. Botes and T. E. Cloete, "The potential of nanofibers and nanobiocides in water purification," Critical Reviews in Microbiology, vol. 36, no. 1, pp. 68-81, 2010.

[136] H. J. Jeon, J. S. Kim, T. G. Kim, J. H. Kim, W.-R. Yu, and J. H. Youk, "Preparation of poly( $\varepsilon$-caprolactone)-based polyurethane nanofibers containing silver nanoparticles," Applied Surface Science, vol. 254, no. 18, pp. 5886-5890, 2008.

[137] N. L. Lala, R. Ramaseshan, L. Bojun et al., "Fabrication of nanofibers with antimicrobial functionality used as filters: protection against bacterial contaminants," Biotechnology and Bioengineering, vol. 97, no. 6, pp. 1357-1365, 2007.

[138] C.-Y. Chen and C.-L. Chiang, "Preparation of cotton fibers with antibacterial silver nanoparticles," Materials Letters, vol. 62, no. 21-22, pp. 3607-3609, 2008.

[139] K. Vimala, K. Samba Sivudu, Y. Murali Mohan, B. Sreedhar, and K. Mohana Raju, "Controlled silver nanoparticles synthesis in semi-hydrogel networks of poly(acrylamide) and carbohydrates: a rational methodology for antibacterial application," Carbohydrate Polymers, vol. 75, no. 3, pp. 463-471, 2009.

[140] M. Peter-Varbanets, C. Zurbrügg, C. Swartz, and W. Pronk, "Decentralized systems for potable water and the potential of membrane technology," Water Research, vol. 43, no. 2, pp. 245265, 2009.

[141] K. Zodrow, L. Brunet, S. Mahendra et al., "Polysulfone ultrafiltration membranes impregnated with silver nanoparticles show improved biofouling resistance and virus removal," Water Research, vol. 43, no. 3, pp. 715-723, 2009.

[142] H. J. Lee, S. Y. Yeo, and S. H. Jeong, "Antibacterial effect of nanosized silver colloidal solution on textile fabrics," Journal of Materials Science, vol. 38, no. 10, pp. 2199-2204, 2003.

[143] Y. Lv, H. Liu, Z. Wang et al., "Silver nanoparticle-decorated porous ceramic composite for water treatment," Journal of Membrane Science, vol. 331, no. 1-2, pp. 50-56, 2009.

[144] N. Ma, X. Fan, X. Quan, and Y. Zhang, "Ag-TiO $/ 2 / \mathrm{HAP} / \mathrm{Al}_{2} \mathrm{O}_{3}$ bioceramic composite membrane: fabrication, characterization and bactericidal activity," Journal of Membrane Science, vol. 336, no. 1-2, pp. 109-117, 2009.

[145] N. Ma, X. Quan, Y. Zhang, S. Chen, and H. Zhao, "Integration of separation and photocatalysis using an inorganic membrane modified with $\mathrm{Si}$-doped $\mathrm{TiO}_{2}$ for water purification," Journal of Membrane Science, vol. 335, no. 1-2, pp. 58-67, 2009.

[146] B. De Gusseme, T. Hennebel, E. Christiaens et al., "Virus disinfection in water by biogenic silver immobilized in polyvinylidene fluoride membranes," Water Research, vol. 45, no. 4, pp. 1856-1864, 2011.

[147] H. Ma, B. S. Hsiao, and B. Chu, "Thin-film nanofibrous composite membranes containing cellulose or chitin barrier layers fabricated by ionic liquids," Polymer, vol. 52, no. 12, pp. 2594-2599, 2011.

[148] M. S. Mauter, Y. Wang, K. C. Okemgbo, C. O. Osuji, E. P. Giannelis, and M. Elimelech, "Antifouling ultrafiltration membranes via post-fabrication grafting of biocidal nanomaterials," ACS Applied Materials and Interfaces, vol. 3, no. 8, pp. 2861-2868, 2011.

[149] W.-L. Chou, D.-G. Yu, and M.-C. Yang, "The preparation and characterization of silver-loading cellulose acetate hollow fiber membrane for water treatment," Polymers for Advanced Technologies, vol. 16, no. 8, pp. 600-607, 2005.

[150] S. Y. Lee, H. J. Kim, R. Patel, S. J. Im, J. H. Kim, and B. R. Min, "Silver nanoparticles immobilized on thin film composite polyamide membrane: characterization, nanofiltration, antifouling properties," Polymers for Advanced Technologies, vol. 18, no. 7, pp. 562-568, 2007.

[151] S. Chaturvedi, P. N. Dave, and N. K. Shah, "Applications of nano-catalyst in new era," Journal of Saudi Chemical Society, vol. 16, no. 3, pp. 307-325, 2012.

[152] D.-G. Yu, M.-Y. Teng, W.-L. Chou, and M.-C. Yang, "Characterization and inhibitory effect of antibacterial PAN-based hollow fiber loaded with silver nitrate," Journal of Membrane Science, vol. 225, no. 1-2, pp. 115-123, 2003. 
[153] J. S. Taurozzi, H. Arul, V. Z. Bosak et al., "Effect of filler incorporation route on the properties of polysulfone-silver nanocomposite membranes of different porosities," Journal of Membrane Science, vol. 325, no. 1, pp. 58-68, 2008.

[154] A. A. Adesina, "Industrial exploitation of photocatalysis: progress, perspectives and prospects," Catalysis Surveys from Asia, vol. 8, no. 4, pp. 265-273, 2004.

[155] Q. Li, S. Mahendra, D. Y. Lyon et al., "Antimicrobial nanomaterials for water disinfection and microbial control: potential applications and implications," Water Research, vol. 42, no. 18, pp. 4591-4602, 2008.

[156] K. Hashimoto, H. Irie, and A. Fujishima, " $\mathrm{TiO}_{2}$ photocatalysis: a historical overview and future prospects," Japanese Journal of Applied Physics, Part 1: Regular Papers and Short Notes and Review Papers, vol. 44, no. 12, pp. 8269-8285, 2005.

[157] H. Einaga, S. Futamura, and T. Ibusuki, "Photocatalytic decomposition of benzene over $\mathrm{TiO}_{2}$ in a humidified airstream," Physical Chemistry Chemical Physics, vol. 1, no. 20, pp. 49034908, 1999.

[158] A. Fujishima, T. N. Rao, and D. A. Tryk, "Titanium dioxide photocatalysis," Journal of Photochemistry and Photobiology C: Photochemistry Reviews, vol. 1, no. 1, pp. 1-21, 2000.

[159] G. S. Shephard, S. Stockenström, D. De Villiers, W. J. Engelbrecht, and G. F. S. Wessels, "Degradation of microcystin toxins in a falling film photocatalytic reactor with immobilized titanium dioxide catalyst," Water Research, vol. 36, no. 1, pp. 140146, 2002.

[160] J. A. Ibáñez, M. I. Litter, and R. A. Pizarro, "Photocatalytic bactericidal effect of $\mathrm{TiO}_{2}$ on Enterobacter cloacae. Comparative study with other Gram (-) bacteria," Journal of Photochemistry and Photobiology A: Chemistry, vol. 157, no. 1, pp. 81-85, 2003.

[161] H.-L. Liu and T. C.-K. Yang, "Photocatalytic inactivation of Escherichia coli and Lactobacillus helveticus by $\mathrm{ZnO}$ and $\mathrm{TiO}_{2}$ activated with ultraviolet light," Process Biochemistry, vol. 39, no. 4, pp. 475-481, 2003.

[162] M. Cho, H. Chung, W. Choi, and J. Yoon, "Linear correlation between inactivation of $E$. coli and $\mathrm{OH}$ radical concentration in $\mathrm{TiO}_{2}$ photocatalytic disinfection," Water Research, vol. 38, no. 4, pp. 1069-1077, 2004.

[163] M. Cho, H. Chung, W. Choi, and J. Yoon, "Different inactivation behaviors of MS-2 phage and Escherichia coli in $\mathrm{TiO}_{2}$ photocatalytic disinfection," Applied and Environmental Microbiology, vol. 71, no. 1, pp. 270-275, 2005.

[164] P. Hajkova, P. Spatenka, J. Horsky, I. Horska, and A. Kolouch, "Photocatalytic effect of $\mathrm{TiO}_{2}$ films on viruses and bacteria," Plasma Processes and Polymers, vol. 4, no. 1, pp. S397-S401, 2007.

[165] L. Zan, W. Fa, T. Peng, and Z.-K. Gong, "Photocatalysis effect of nanometer $\mathrm{TiO}_{2}$ and $\mathrm{TiO}_{2}$-coated ceramic plate on Hepatitis B virus," Journal of Photochemistry and Photobiology B: Biology, vol. 86, no. 2, pp. 165-169, 2007.

[166] J. Lonnen, S. Kilvington, S. C. Kehoe, F. Al-Touati, and K. G. McGuigan, "Solar and photocatalytic disinfection of protozoan, fungal and bacterial microbes in drinking water," Water Research, vol. 39, no. 5, pp. 877-883, 2005.

[167] S. Gelover, L. A. Gómez, K. Reyes, and M. Teresa Leal, “A practical demonstration of water disinfection using $\mathrm{TiO}_{2}$ films and sunlight," Water Research, vol. 40, no. 17, pp. 3274-3280, 2006.

[168] M. Ni, M. K. H. Leung, D. Y. C. Leung, and K. Sumathy, "A review and recent developments in photocatalytic watersplitting using $\mathrm{TiO}_{2}$ for hydrogen production," Renewable and Sustainable Energy Reviews, vol. 11, no. 3, pp. 401-425, 2007.
[169] A. Fujishima, X. Zhang, and D. A. Tryk, " $\mathrm{TiO}_{2}$ photocatalysis and related surface phenomena," Surface Science Reports, vol. 63 , no. 12 , pp. 515-582, 2008.

[170] V. Subramanian, E. Wolf, and P. V. Kamat, "Semiconductormetal composite nanostructures. To what extent do metal nanoparticles improve the photocatalytic activity of $\mathrm{TiO}_{2}$ films?" Journal of Physical Chemistry B, vol. 105, no. 46, pp. 11439-11446, 2001.

[171] R. Asahi, T. Morikawa, T. Ohwaki, K. Aoki, and Y. Taga, "Visible-light photocatalysis in nitrogen-doped titanium oxides," Science, vol. 293, no. 5528, pp. 269-271, 2001.

[172] C. Burda, Y. Lou, X. Chen, A. C. S. Samia, J. Stout, and J. L. Gole, "Enhanced nitrogen doping in $\mathrm{TiO}_{2}$ nanoparticles," Nano Letters, vol. 3, no. 8, pp. 1049-1051, 2003.

[173] H. Irie, Y. Watanabe, and K. Hashimoto, "Nitrogen-concentration dependence on photocatalytic activity of $\mathrm{TiO}_{2}-\mathrm{xNx}$ powders," Journal of Physical Chemistry B, vol. 107, no. 23, pp. 5483-5486, 2003.

[174] O. Diwald, T. L. Thompson, T. Zubkov, E. G. Goralski, S. D. Walck, and J. T. Yates Jr., "Photochemical activity of nitrogendoped rutile $\mathrm{TiO}_{2}$ (110) in visible light," Journal of Physical Chemistry B, vol. 108, no. 19, pp. 6004-6008, 2004.

[175] S. Yang and L. Gao, "New method to prepare nitrogen-doped titanium dioxide and its photocatalytic activities irradiated by visible light," Journal of the American Ceramic Society, vol. 87, no. 9, pp. 1803-1805, 2004.

[176] C. Di Valentin, G. Pacchioni, and A. Selloni, "Origin of the different photoactivity of $\mathrm{N}$-doped anatase and rutile $\mathrm{TiO}_{2}$," Physical Review B-Condensed Matter and Materials Physics, vol. 70, no. 8, Article ID 85116, 2004.

[177] S. Livraghi, A. Votta, M. C. Paganini, and E. Giamello, "The nature of paramagnetic species in nitrogen doped $\mathrm{TiO}_{2}$ active in visible light photocatalysis," Chemical Communications, no. 4, pp. 498-500, 2005.

[178] S. Livraghi, M. C. Paganini, E. Giamello, A. Selloni, C. Di Valentin, and G. Pacchioni, "Origin of photoactivity of nitrogen-doped titanium dioxide under visible light," Journal of the American Chemical Society, vol. 128, no. 49, pp. 15666-15671, 2006.

[179] Y. Liu, J. Li, X. Qiu, and C. Burda, "Novel $\mathrm{TiO}_{2}$ nanocatalysts for wastewater purification: tapping energy from the sun," Water Science and Technology, vol. 54, no. 8, pp. 47-54, 2006.

[180] M.-S. Wong, W.-C. Chu, D.-S. Sun et al., "Visible-light-induced bactericidal activity of a nitrogen-doped titanium photocatalyst against human pathogens," Applied and Environmental Microbiology, vol. 72, no. 9, pp. 6111-6116, 2006.

[181] S. U. M. Khan, M. Al-Shahry, and W. B. Ingler Jr., "Efficient photochemical water splitting by a chemically modified n$\mathrm{TiO}_{2}$," Science, vol. 297, no. 5590, pp. 2243-2245, 2002.

[182] S. Sakthivel and H. Kisch, "Daylight photocatalysis by carbon-modified titanium dioxide," Angewandte ChemieInternational Edition, vol. 42, no. 40, pp. 4908-4911, 2003.

[183] K. Noworyta and J. Augustynski, "Spectral photoresponses of carbon-doped $\mathrm{TiO}_{2}$ film electrodes," Electrochemical and SolidState Letters, vol. 7, no. 6, pp. E31-E33, 2004.

[184] L. Lin, W. Lin, Y. X. Zhu et al., "Uniform carbon-covered titania and its photocatalytic property," Journal of Molecular Catalysis A: Chemical, vol. 236, no. 1-2, pp. 46-53, 2005.

[185] M. E. Rincón, M. E. Trujillo-Camacho, and A. K. CuentasGallegos, "Sol-gel titanium oxides sensitized by nanometric 
carbon blacks: comparison with the optoelectronic and photocatalytic properties of physical mixtures," Catalysis Today, vol. 107-108, pp. 606-611, 2005.

[186] H. Wang and J. P. Lewis, "Effects of dopant states on photoactivity in carbon-doped $\mathrm{TiO}_{2}$," Journal of Physics Condensed Matter, vol. 17, no. 21, pp. L209-L213, 2005.

[187] D. Mitoraj, A. Jańczyk, M. Strus et al., "Visible light inactivation of bacteria and fungi by modified titanium dioxide," Photochemical and Photobiological Sciences, vol. 6, no. 6, pp. 642-648, 2007.

[188] T. Umebayashi, T. Yamaki, H. Itoh, and K. Asai, "Band gap narrowing of titanium dioxide by sulfur doping," Applied Physics Letters, vol. 81, no. 3, pp. 454-456, 2002.

[189] T. Ohno, T. Mitsui, and M. Matsumura, "Photocatalytic activity of S-doped $\mathrm{TiO}_{2}$ photocatalyst under visible light," Chemistry Letters, vol. 32, no. 4, pp. 364-365, 2003.

[190] T. Yamamoto, F. Yamashita, I. Tanaka, E. Matsubara, and A. Muramatsu, "Electronic states of sulfur doped $\mathrm{TiO}_{2}$ by first principles calculations," Materials Transactions, vol. 45, no. 7, pp. 1987-1990, 2004.

[191] J. C. Yu, J. Yu, W. Ho, Z. Jiang, and L. Zhang, "Effects of Fdoping on the photocatalytic activity and microstructures of nanocrystalline $\mathrm{TiO}_{2}$ powders," Chemistry of Materials, vol. 14, no. 9, pp. 3808-3816, 2002.

[192] M. Sökmen, F. Candan, and Z. Sümer, "Disinfection of $E$. coli by the $\mathrm{Ag}-\mathrm{TiO}_{2} / \mathrm{UV}$ system: lipidperoxidation," Journal of Photochemistry and Photobiology A: Chemistry, vol. 143, no. 2-3, pp. 241-244, 2001.

[193] H. M. Sung-Suh, J. R. Choi, H. J. Hah, S. M. Koo, and Y. C. Bae, "Comparison of Ag deposition effects on the photocatalytic activity of nanoparticulate $\mathrm{TiO}_{2}$ under visible and UV light irradiation," Journal of Photochemistry and Photobiology A: Chemistry, vol. 163, no. 1-2, pp. 37-44, 2004.

[194] V. Vamathevan, R. Amal, D. Beydoun, G. Low, and S. McEvoy, "Silver metallisation of titania particles: effects on photoactivity for the oxidation of organics," Chemical Engineering Journal, vol. 98, no. 1-2, pp. 127-139, 2004.

[195] X. Zhang, M. Zhou, and L. Lei, "Preparation of an Ag$\mathrm{TiO}_{2}$ photocatalyst coated on activated carbon by MOCVD," Materials Chemistry and Physics, vol. 91, no. 1, pp. 73-79, 2005.

[196] K. Page, R. G. Palgrave, I. P. Parkin, M. Wilson, S. L. P. Savin, and A. V. Chadwick, "Titania and silver-titania composite films on glass-potent antimicrobial coatings," Journal of Materials Chemistry, vol. 17, no. 1, pp. 95-104, 2007.

[197] M. V. Liga, E. L. Bryant, V. L. Colvin, and Q. Li, "Virus inactivation by silver doped titanium dioxide nanoparticles for drinking water treatment," Water Research, vol. 45, no. 2, pp. 535-544, 2011.

[198] E. Bae and W. Choi, "Highly enhanced photoreductive degradation of perchlorinated compounds on dye-sensitized metal/ $\mathrm{TiO}_{2}$ under visible light," Environmental Science and Technology, vol. 37, no. 1, pp. 147-152, 2003.

[199] J. C. Ireland, P. Klostermann, E. W. Rice, and R. M. Clark, "Inactivation of Escherichia coli by titanium dioxide photocatalytic oxidation," Applied and Environmental Microbiology, vol. 59, no. 5, pp. 1668-1670, 1993.

[200] C. Wei, W.-Y. Lin, Z. Zalnal et al., "Bactericidal activity of $\mathrm{TiO}_{2}$ photocatalyst in aqueous media: toward a solar-assisted water disinfection system," Environmental Science and Technology, vol. 28, no. 5, pp. 934-938, 1994.

[201] M. Bekbölet and C. V. Araz, "Inactivation of Escherichia coli by photocatalytic oxidation," Chemosphere, vol. 32, no. 5, pp. 959$965,1996$.
[202] P.-C. Maness, S. Smolinski, D. M. Blake, Z. Huang, E. J. Wolfrum, and W. A. Jacoby, "Bactericidal activity of photocatalytic $\mathrm{TiO}_{2}$ reaction: toward an understanding of its killing mechanism," Applied and Environmental Microbiology, vol. 65, no. 9, pp. 4094-4098, 1999.

[203] J. C. Yu, W. Ho, J. Yu, H. Yip, K. W. Po, and J. Zhao, "Efficient visible-light-induced photocatalytic disinfection on sulfur-doped nanocrystalline titania," Environmental Science and Technology, vol. 39, no. 4, pp. 1175-1179, 2005.

[204] T. A. Egerton, S. A. M. Kosa, and P. A. Christensen, "Photoelectrocatalytic disinfection of E. coli suspensions by iron doped $\mathrm{TiO}_{2}$," Physical Chemistry Chemical Physics, vol. 8, no. 3, pp. 398-406, 2006.

[205] P. Wu, R. Xie, and J. K. Shang, "Enhanced visible-light photocatalytic disinfection of bacterial spores by palladiummodified nitrogen-doped titanium oxide," Journal of the American Ceramic Society, vol. 91, no. 9, pp. 2957-2962, 2008.

[206] P. Wu, R. Xie, J. A. Imlay, and J. K. Shang, "Visible-lightinduced photocatalytic inactivation of bacteria by composite photocatalysts of palladium oxide and nitrogen-doped titanium oxide," Applied Catalysis B: Environmental, vol. 88, no. 3-4, pp. 576-581, 2009.

[207] H. Choi, S. R. Al-Abed, and D. D. Dionysiou, "Nanostructured titanium oxide film- and membrane-based photocatalysis for water treatment," in Nanotechnology Applications for Clean Water, N. Savage, M. Diallo, J. Duncan, A. Street, and R. Sustich, Eds., chapter 3, pp. 39-46, William Andrew, Boston, Mass, USA, 2009.

[208] L. Belháčová, J. Krýsa, J. Geryk, and J. Jirkovský, "Inactivation of microorganisms in a flow-through photoreactor with an immobilized $\mathrm{TiO}_{2}$ layer," Journal of Chemical Technology and Biotechnology, vol. 74, no. 2, pp. 149-154, 1999.

[209] S.-Y. Kwak, S. H. Kim, and S. S. Kim, "Hybrid organic/inorganic reverse osmosis (RO) membrane for bactericidal anti-fouling. 1. Preparation and characterization of $\mathrm{TiO}_{2}$ nanoparticle selfassembled aromatic polyamide thin-film-composite (TFC) membrane," Environmental Science and Technology, vol. 35, no. 11, pp. 2388-2394, 2001.

[210] J. Joo, S. G. Kwon, T. Yu et al., "Large-scale synthesis of $\mathrm{TiO}_{2}$ nanorods via nonhydrolytic sol-gel ester elimination reaction and their application to photocatalytic inactivation of E. coli," Journal of Physical Chemistry B, vol. 109, no. 32, pp. 15297-15302, 2005.

[211] K.-J. Shieh, M. Li, Y.-H. Lee, S.-D. Sheu, Y.-T. Liu, and Y.-C. Wang, "Antibacterial performance of photocatalyst thin film fabricated by defection effect in visible light," Nanomedicine: Nanotechnology, Biology, and Medicine, vol. 2, no. 2, pp. 121-126, 2006.

[212] K. Sunada, T. Watanabe, and K. Hashimoto, "Studies on photokilling of bacteria on $\mathrm{TiO}_{2}$ thin film," Journal of Photochemistry and Photobiology A: Chemistry, vol. 156, no. 1-3, pp. 227233, 2003.

[213] J. Kiwi and V. Nadtochenko, "Evidence for the mechanism of photocatalytic degradation of the bacterial wall membrane at the $\mathrm{TiO}_{2}$ interface by ATR-FTIR and laser kinetic spectroscopy," Langmuir, vol. 21, no. 10, pp. 4631-4641, 2005.

[214] S.-H. Lee, S. Pumprueg, B. Moudgil, and W. Sigmund, "Inactivation of bacterial endospores by photocatalytic nanocomposites," Colloids and Surfaces B: Biointerfaces, vol. 40, no. 2, pp. 93-98, 2005.

[215] D. M. A. Alrousan, P. S. M. Dunlop, T. A. McMurray, and J. A. Byrne, "Photocatalytic inactivation of E. coli in surface water 
using immobilised nanoparticle $\mathrm{TiO}_{2}$ films," Water Research, vol. 43, no. 1, pp. 47-54, 2009.

[216] A. Kubacka, M. Ferrer, M. L. Cerrada et al., "Boosting $\mathrm{TiO}_{2}$-anatase antimicrobial activity: polymer-oxide thin films," Applied Catalysis B: Environmental, vol. 89, no. 3-4, pp. 441-447, 2009.

[217] Y. Zhu, T. Ran, Y. Li, J. Guo, and W. Li, "Dependence of the cytotoxicity of multi-walled carbon nanotubes on the culture medium," Nanotechnology, vol. 17, no. 18, article 024, pp. 46684674, 2006.

[218] S. Deng, V. K. K. Upadhyayula, G. B. Smith, and M. C. Mitchell, "Adsorption equilibrium and kinetics of microorganisms on single-wall carbon nanotubes," IEEE Sensors Journal, vol. 8, no. 6, pp. 954-962, 2008.

[219] D. Nepal, S. Balasubramanian, A. L. Simonian, and V. A. Davis, "Strong antimicrobial coatings: single-walled carbon nanotubes armored with biopolymers," Nano Letters, vol. 8, no. 7, pp. 18961901, 2008.

[220] V. K. K. Upadhyayula, S. Deng, M. C. Mitchell, G. B. Smith, V. K. Nair, and S. Ghoshroy, "Adsorption kinetics of Escherichia coli and Staphylococcus aureus on single-walled carbon nanotube aggregates," Water Science and Technology, vol. 58, no. 1, pp. 179184,2008

[221] V. K. K. Upadhyayula, S. Ghoshroy, V. S. Nair, G. B. Smith, M. C. Mitchell, and S. Deng, "Single-walled carbon nanotubes as fluorescence biosensors for pathogen recognition in water systems," Research Letters in Nanotechnology, vol. 2008, Article ID 156358, 5 pages, 2008.

[222] T. Akasaka and F. Watari, "Capture of bacteria by flexible carbon nanotubes," Acta Biomaterialia, vol. 5, no. 2, pp. 607-612, 2009.

[223] A. S. Brady-Estévez, S. Kang, and M. Elimelech, "A singlewalled-carbon-nanotube filter for removal of viral and bacterial pathogens," Small, vol. 4, no. 4, pp. 481-484, 2008.

[224] S. T. Mostafavi, M. R. Mehrnia, and A. M. Rashidi, "Preparation of nanofilter from carbon nanotubes for application in virus removal from water," Desalination, vol. 238, no. 1-3, pp. 271-280, 2009.

[225] R. Q. Long and R. T. Yang, "Carbon nanotubes as superior sorbent for dioxin removal," Journal of the American Chemical Society, vol. 123, no. 9, pp. 2058-2059, 2001.

[226] H. Yan, G. Pan, H. Zou, X. Li, and H. Chen, "Effective removal of microcystins using carbon nanotubes embedded with bacteria," Chinese Science Bulletin, vol. 49, no. 16, pp. 1694-1698, 2004.

[227] C. Ye, Q. Gong, F. Lu, and J. Liang, "Adsorption of middle molecular weight toxins on carbon nanotubes," Acta PhysicoChimica Sinica, vol. 23, no. 9, pp. 1321-1324, 2007.

[228] E. C. de Albuquerque Jr., M. O. A. Méndez, A. dos Reis Coutinho, and T. T. Franco, "Removal of cyanobacteria toxins from drinking water by adsorption on activated carbon fibers," Materials Research, vol. 11, no. 3, pp. 371-380, 2008.

[229] V. K. K. Upadhyayula, S. Deng, M. C. Mitchell, and G. B. Smith, "Application of carbon nanotube technology for removal of contaminants in drinking water: a review," Science of the Total Environment, vol. 408, no. 1, pp. 1-13, 2009.

[230] S. Kang, M. Pinault, L. D. Pfefferle, and M. Elimelech, "Singlewalled carbon nanotubes exhibit strong antimicrobial activity," Langmuir, vol. 23, no. 17, pp. 8670-8673, 2007.

[231] S. Kang, M. Herzberg, D. F. Rodrigues, and M. Elimelech, "Antibacterial effects of carbon nanotubes: size does matter!", Langmuir, vol. 24, no. 13, pp. 6409-6413, 2008.
[232] P. Wick, P. Manser, L. K. Limbach et al., "The degree and kind of agglomeration affect carbon nanotube cytotoxicity," Toxicology Letters, vol. 168, no. 2, pp. 121-131, 2007.

[233] C. D. Vecitis, K. R. Zodrow, S. Kang, and M. Elimelech, "Electronic-structure-dependent bacterial cytotoxicity of single-walled carbon nanotubes," ACS Nano, vol. 4, no. 9, pp. 5471-5479, 2010.

[234] S. Kang, M. S. Mauter, and M. Elimelech, "Physicochemical determinants of multiwalled carbon nanotube bacterial cytotoxicity," Environmental Science and Technology, vol. 42, no. 19, pp. 7528-7534, 2008.

[235] L. R. Arias and L. Yang, "Inactivation of bacterial pathogens by carbon nanotubes in suspensions," Langmuir, vol. 25, no. 5, pp. 3003-3012, 2009.

[236] G. Jia, H. Wang, L. Yan et al., "Cytotoxicity of carbon nanomaterials: single-wall nanotube, multi-wall nanotube, and fullerene," Environmental Science and Technology, vol. 39, no. 5, pp. 1378$1383,2005$.

[237] K. Donaldson, R. Aitken, L. Tran et al., "Carbon nanotubes: a review of their properties in relation to pulmonary toxicology and workplace safety," Toxicological Sciences, vol. 92, no. 1, pp. 5-22, 2006.

[238] H. Dumortier, S. Lacotte, G. Pastorin et al., "Functionalized carbon nanotubes are non-cytotoxic and preserve the functionality of primary immune cells," Nano Letters, vol. 6, no. 7, pp. 15221528, 2006.

[239] M. Endo, T. Hayashi, and Y.-A. Kim, "Large-scale production of carbon nanotubes and their applications," Pure and Applied Chemistry, vol. 78, no. 9, pp. 1703-1713, 2006.

[240] J. B. Nuzzo, “The biological threat to U.S. water supplies: toward a national water security policy," Biosecurity and Bioterrorism, vol. 4, no. 2, pp. 147-159, 2006.

[241] J. J. Niu, J. N. Wang, Y. Jiang, L. F. Su, and J. Ma, "An approach to carbon nanotubes with high surface area and large pore volume," Microporous and Mesoporous Materials, vol. 100, no. 1-3, pp. 1-5, 2007.

[242] S. Kar, R. C. Bindal, S. Prabhakar, P. K. Tewari, K. Dasgupta, and D. Sathiyamoorthy, "Potential of carbon nanotubes in water purification: an approach towards the development of an integrated membrane system," International Journal of Nuclear Desalination, vol. 3, no. 2, pp. 143-150, 2008.

[243] M. L. Jugan, L. Oziol, M. Bimbot et al., "In vitro assessment of thyroid and estrogenic endocrine disruptors in wastewater treatment plants, rivers and drinking water supplies in the greater Paris area (France)," Science of the Total Environment, vol. 407, no. 11, pp. 3579-3587, 2009.

[244] H. Liu, J. Ru, J. Qu, R. Dai, Z. Wang, and C. Hu, "Removal of persistent organic pollutants from micro-polluted drinking water by triolein embedded absorbent," Bioresource Technology, vol. 100, no. 12, pp. 2995-3002, 2009.

[245] A. S. Brady-Estévez, M. H. Schnoor, S. Kang, and M. Elimelech, "SWNT-MWNT hybrid filter attains high viral removal and bacterial inactivation," Langmuir, vol. 26, no. 24, pp. 1915319158, 2010.

[246] C. D. Vecitis, M. H. Schnoor, M. S. Rahaman, J. D. Schiffman, and M. Elimelech, "Electrochemical multiwalled carbon nanotube filter for viral and bacterial removal and inactivation," Environmental Science and Technology, vol. 45, no. 8, pp. 36723679, 2011.

[247] M. S. Rahaman, C. D. Vecitis, and M. Elimelech, "Electrochemical carbon-nanotube filter performance toward virus removal 
and inactivation in the presence of natural organic matter," Environmental Science and Technology, vol. 46, no. 3, pp. 15561564, 2012.

[248] F. Ahmed, C. M. Santos, R. A. M. V. Vergara, M. C. R. Tria, R. Advincula, and D. F. Rodrigues, "Antimicrobial applications of electroactive PVK-SWNT nanocomposites," Environmental Science and Technology, vol. 46, no. 3, pp. 1804-1810, 2012.

[249] A. Tiraferri, C. D. Vecitis, and M. Elimelech, "Covalent binding of single-walled carbon nanotubes to polyamide membranes for antimicrobial surface properties," ACS Applied Materials and Interfaces, vol. 3, no. 8, pp. 2869-2877, 2011.

[250] P. Gong, H. Li, X. He et al., "Preparation and antibacterial activity of Fe3O4@Ag nanoparticles," Nanotechnology, vol. 18, no. 28, Article ID 285604, 2007.

[251] W.-J. Chen, P.-J. Tsai, and Y.-C. Chen, "Functional Fe3O4/TiO2 core/shell magnetic nanoparticles as photokilling agents for pathogenic bacteria," Small, vol. 4, no. 4, pp. 485-491, 2008.

[252] O. B. Koper, J. S. Klabunde, G. L. Marchin, K. J. Klabunde, P. Stoimenov, and L. Bohra, "Nanoscale powders and formulations with biocidal activity toward spores and vegetative cells of Bacillus species, viruses, and toxins," Current Microbiology, vol. 44, no. 1, pp. 49-55, 2002.

[253] P. K. Stoimenov, R. L. Klinger, G. L. Marchin, and K. J. Klabunde, "Metal oxide nanoparticles as bactericidal agents," Langmuir, vol. 18, no. 17, pp. 6679-6686, 2002.

[254] M. A. Gondal, M. A. Dastageer, and A. Khalil, "Synthesis of nano-WO3 and its catalytic activity for enhanced antimicrobial process for water purification using laser induced photocatalysis," Catalysis Communications, vol. 11, no. 3, pp. 214-219, 2009.

[255] A. Khalil, M. A. Gondal, and M. A. Dastageer, "Augmented photocatalytic activity of palladium incorporated $\mathrm{ZnO}$ nanoparticles in the disinfection of Escherichia coli microorganism from water," Applied Catalysis A: General, vol. 402, no. 1-2, pp. 162167, 2011.

[256] H. Bai, Z. liu, and D. D. Sun, "Hierarchical ZnO nanostructured membrane for multifunctional environmental applications," Colloids and Surfaces A: Physicochemical and Engineering Aspects, vol. 410, pp. 11-17, 2012.

[257] T. Humplik, J. Lee, S. C. O'Hern et al., "Nanostructured materials for water desalination," Nanotechnology, vol. 22, no. 29, Article ID 292001, 2011.

[258] C. Fritzmann, J. Löwenberg, T. Wintgens, and T. Melin, "Stateof-the-art of reverse osmosis desalination," Desalination, vol. 216, no. 1-3, pp. 1-76, 2007.

[259] M. S. Mohsen, J. O. Jaber, and M. D. Afonso, "Desalination of brackish water by nanofiltration and reverse osmosis," Desalination, vol. 157, no. 1-3, p. 167, 2003.

[260] A. Srivastava, O. N. Srivastava, S. Talapatra, R. Vajtai, and P. M. Ajayan, "Carbon nanotube filters," Nature Materials, vol. 3, no. 9, pp. 610-614, 2004.

[261] J. K. Holt, H. G. Park, Y. Wang et al., "Fast mass transport through sub-2-nanometer carbon nanotubes," Science, vol. 312, no. 5776, pp. 1034-1037, 2006.

[262] F. Fornasiero, G. P. Hyung, J. K. Holt et al., "Ion exclusion by sub-2-nm carbon nanotube pores," Proceedings of the National Academy of Sciences of the United States of America, vol. 105, no. 45, pp. 17250-17255, 2008.

[263] L. Li, J. Dong, T. M. Nenoff, and R. Lee, "Desalination by reverse osmosis using MFI zeolite membranes," Journal of Membrane Science, vol. 243, no. 1-2, pp. 401-404, 2004.
[264] L. Li, N. Liu, B. McPherson, and R. Lee, "Influence of counter ions on the reverse osmosis through MFI zeolite membranes: implications for produced water desalination," Desalination, vol. 228, no. 1-3, pp. 217-225, 2008.

[265] K. Sint, B. Wang, and P. Král, "Selective ion passage through functionalized graphene nanopores," Journal of the American Chemical Society, vol. 130, no. 49, pp. 16448-16449, 2008.

[266] D.-E. Jiang, V. R. Cooper, and S. Dai, "Porous graphene as the ultimate membrane for gas separation," Nano Letters, vol. 9, no. 12, pp. 4019-4024, 2009.

[267] J. Bai, X. Zhong, S. Jiang, Y. Huang, and X. Duan, "Graphene nanomesh," Nature Nanotechnology, vol. 5, no. 3, pp. 190-194, 2010.

[268] C. L. Pint, S. T. Pheasant, M. Pasquali, K. E. Coulter, H. K. Schmidt, and R. H. Hauge, "Synthesis of high aspect-ratio carbon nanotube "flying carpets" from nanostructured flake substrates," Nano Letters, vol. 8, no. 7, pp. 1879-1883, 2008.

[269] N. Arjmandi, P. Sasanpour, and B. Rashidian, "CVD synthesis of small-diameter Single-Walled carbon nanotubes on silicon," Scientia Iranica, vol. 16, no. 1 D, pp. 61-64, 2009.

[270] C. Song and B. Corry, "Intrinsic ion selectivity of narrow hydrophobic pores," Journal of Physical Chemistry B, vol. 113, no. 21, pp. 7642-7649, 2009.

[271] H. S. Lee, S. J. Im, J. H. Kim, H. J. Kim, J. P. Kim, and B. R. Min, "Polyamide thin-film nanofiltration membranes containing $\mathrm{TiO}_{2}$ nanoparticles," Desalination, vol. 219, no. 1-3, pp. 48-56, 2008.

[272] M. M. Cortalezzi, J. Rose, A. R. Barron, and M. R. Wiesner, "Characteristics of ultrafiltration ceramic membranes derived from alumoxane nanoparticles," Journal of Membrane Science, vol. 205, no. 1-2, pp. 33-43, 2002.

[273] B. S. Karnik, S. H. Davies, M. J. Baumann, and S. J. Masten, "Fabrication of catalytic membranes for the treatment of drinking water using combined ozonation and ultrafiltration," Environmental Science and Technology, vol. 39, no. 19, pp. 76567661, 2005.

[274] M. C. Duke, S. Mee, and J. C. D. da Costa, "Performance of porous inorganic membranes in non-osmotic desalination," Water Research, vol. 41, no. 17, pp. 3998-4004, 2007.

[275] B.-H. Jeong, E. M. V. Hoek, Y. Yan et al., "Interfacial polymerization of thin film nanocomposites: a new concept for reverse osmosis membranes," Journal of Membrane Science, vol. 294, no. 1-2, pp. 1-7, 2007.

[276] L. Li and R. Lee, "Purification of produced water by ceramic membranes: material screening, process design and economics," Separation Science and Technology, vol. 44, no. 15, pp. 3455-3484, 2009.

[277] M. E. Suk and N. R. Aluru, "Water transport through ultrathin graphene," Journal of Physical Chemistry Letters, vol. 1, no. 10, pp. 1590-1594, 2010.

[278] X. Gong, J. Li, H. Lu et al., "A charge-driven molecular water pump," Nature Nanotechnology, vol. 2, no. 11, pp. 709-712, 2007.

[279] C. C. Striemer, T. R. Gaborski, J. L. McGrath, and P. M. Fauchet, "Charge- and size-based separation of macromolecules using ultrathin silicon membranes," Nature, vol. 445, no. 7129, pp. 749-753, 2007.

[280] G. Zuo, R. Shen, S. Ma, and W. Guo, “Transport properties of single-file water molecules inside a carbon nanotube biomimicking water channel," ACS Nano, vol. 4, no. 1, pp. 205-210, 2010.

[281] E. M. V. Hoek and A. K. Ghosh, "Nanotechnology-Based Membranes for Water Purification," in Nanotechnology Applications 
for Clean Water, N. Savage, M. Diallo, J. Duncan, A. Street, and R. Sustich, Eds., chapter 4, pp. 47-58, William Andrew, Boston, Mass, USA, 2009.

[282] M. L. Lind, A. K. Ghosh, A. Jawor et al., "Influence of zeolite crystal size on zeolite-polyamide thin film nanocomposite membranes," Langmuir, vol. 25, no. 17, pp. 10139-10145, 2009.

[283] M. L. Lind, D. E. Suk, T.-V. Nguyen, and E. M. V. Hoek, “Tailoring the structure of thin film nanocomposite membranes to achieve seawater RO membrane performance," Environmental Science and Technology, vol. 44, no. 21, pp. 8230-8235, 2010.

[284] P. Nednoor, N. Chopra, V. Gavalas, L. G. Bachas, and B. J. Hinds, "Reversible biochemical switching of ionic transport through aligned carbon nanotube membranes," Chemistry of Materials, vol. 17, no. 14, pp. 3595-3599, 2005.

[285] M. S. Mauter and M. Elimelech, "Environmental applications of carbon-based nanomaterials," Environmental Science and Technology, vol. 42, no. 16, pp. 5843-5859, 2008.

[286] B. Hinds, "Dramatic transport properties of carbon nanotube membranes for a robust protein channel mimetic platform," Current Opinion in Solid State and Materials Science, vol. 16, no. 1, pp. 1-9, 2012.

[287] G. P. Rao, C. Lu, and F. Su, "Sorption of divalent metal ions from aqueous solution by carbon nanotubes: a review," Separation and Purification Technology, vol. 58, no. 1, pp. 224-231, 2007.

[288] Y.-H. Li, J. Ding, Z. Luan et al., "Competitive adsorption of $\mathrm{Pb}^{+}, \mathrm{Cu}^{+}$and $\mathrm{Cd} 2^{+}$ions from aqueous solutions by multiwalled carbon nanotubes," Carbon, vol. 41, no. 14, pp. 2787-2792, 2003.

[289] Z.-C. Di, J. Ding, X.-J. Peng, Y.-H. Li, Z.-K. Luan, and J. Liang, "Chromium adsorption by aligned carbon nanotubes supported ceria nanoparticles," Chemosphere, vol. 62, no. 5, pp. 861-865, 2006.

[290] Y.-H. Li, Z. Di, J. Ding, D. Wu, Z. Luan, and Y. Zhu, "Adsorption thermodynamic, kinetic and desorption studies of $\mathrm{Pb}^{+}$on carbon nanotubes," Water Research, vol. 39, no. 4, pp. 605-609, 2005.

[291] C. Lu, H. Chiu, and C. Liu, "Removal of zinc(II) from aqueous solution by purified carbon nanotubes: kinetics and equilibrium studies," Industrial and Engineering Chemistry Research, vol. 45, no. 8, pp. 2850-2855, 2006.

[292] X. Peng, Z. Luan, J. Ding, Z. Di, Y. Li, and B. Tian, “Ceria nanoparticles supported on carbon nanotubes for the removal of arsenate from water," Materials Letters, vol. 59, no. 4, pp. 399403, 2005.

[293] C. Lu, Y.-L. Chung, and K.-F. Chang, "Adsorption of trihalomethanes from water with carbon nanotubes," Water Research, vol. 39, no. 6, pp. 1183-1189, 2005.

[294] C. Lu and H. Chiu, "Adsorption of zinc(II) from water with purified carbon nanotubes," Chemical Engineering Science, vol. 61, no. 4, pp. 1138-1145, 2006.

[295] K. L. Salipira, B. B. Mamba, R. W. Krause, T. J. Malefetse, and S. H. Durbach, "Carbon nanotubes and cyclodextrin polymers for removing organic pollutants from water," Environmental Chemistry Letters, vol. 5, no. 1, pp. 13-17, 2007.

[296] Y. C. Sharma, V. Srivastava, V. K. Singh, S. N. Kaul, and C. H. Weng, "Nano-adsorbents for the removal of metallic pollutants from water and wastewater," Environmental Technology, vol. 30, no. 6, pp. 583-609, 2009.

[297] E. A. Deliyanni, D. N. Bakoyannakis, A. I. Zouboulis, and K. A. Matis, "Sorption of As(V) ions by akaganéite-type nanocrystals," Chemosphere, vol. 50, no. 1, pp. 155-163, 2003.
[298] J. T. Mayo, C. Yavuz, S. Yean et al., "The effect of nanocrystalline magnetite size on arsenic removal," Science and Technology of Advanced Materials, vol. 8, no. 1-2, pp. 71-75, 2007.

[299] K. Kabra, R. Chaudhary, and R. L. Sawhney, "Treatment of hazardous organic and inorganic compounds through aqueousphase photocatalysis: a review," Industrial and Engineering Chemistry Research, vol. 43, no. 24, pp. 7683-7696, 2004.

[300] M. E. Pena, G. P. Korfiatis, M. Patel, L. Lippincott, and X. Meng, "Adsorption of $\mathrm{As}(\mathrm{V})$ and $\mathrm{As}(\mathrm{III})$ by nanocrystalline titanium dioxide," Water Research, vol. 39, no. 11, pp. 2327-2337, 2005.

[301] K. Zhang, K. C. Kemp, and V. Chandra, "Homogeneous anchoring of $\mathrm{TiO}_{2}$ nanoparticles on graphene sheets for waste water treatment," Materials Letters, vol. 81, pp. 127-130, 2012.

[302] M. A. Omole, I. K'Owino, and O. A. Sadik, "Nanostructured materials for improving water quality: potentials and risks," in Nanotechnology Applications for Clean Water, N. Savage, M. Diallo, J. Duncan, A. Street, and R. Sustich, Eds., chapter 17, pp. 233-247, William Andrew, Boston, Mass, USA, 2009.

[303] C. H. Lai and C. Y. Chen, "Removal of metal ions and humic acid from water by iron-coated filter media," Chemosphere, vol. 44, no. 5, pp. 1177-1184, 2001.

[304] M. S. Onyango, Y. Kojima, H. Matsuda, and A. Ochieng, "Adsorption kinetics of arsenic removal from groundwater by iron-modified zeolite," Journal of Chemical Engineering of Japan, vol. 36, no. 12, pp. 1516-1522, 2003.

[305] L. C. A. Oliveira, D. I. Petkowicz, A. Smaniotto, and S. B. C. Pergher, "Magnetic zeolites: a new adsorbent for removal of metallic contaminants from water," Water Research, vol. 38, no. 17, pp. 3699-3704, 2004.

[306] C. T. Yavuz, J. T. Mayo, W. W. Yu et al., "Low-field magnetic separation of monodisperse Fe3O4 nanocrystals," Science, vol. 314, no. 5801, pp. 964-967, 2006.

[307] M. Takafuji, S. Ide, H. Ihara, and Z. Xu, "Preparation of poly(1vinylimidazole)-grafted magnetic nanoparticles and their application for removal of metal ions," Chemistry of Materials, vol. 16, no. 10, pp. 1977-1983, 2004.

[308] L. Wang, Z. Yang, J. Gao et al., "A biocompatible method of decorporation: bisphosphonate-modified magnetite nanoparticles to remove uranyl ions from blood," Journal of the American Chemical Society, vol. 128, no. 41, pp. 13358-13359, 2006.

[309] S. M. Ponder, J. G. Darab, and T. E. Mallouk, "Remediation of $\mathrm{Cr}(\mathrm{VI})$ and $\mathrm{Pb}(\mathrm{II})$ aqueous solutions using supported, nanoscale zero-valent iron," Environmental Science and Technology, vol. 34, no. 12, pp. 2564-2569, 2000.

[310] S. R. Kanel, B. Manning, L. Charlet, and H. Choi, "Removal of arsenic(III) from groundwater by nanoscale zero-valent iron," Environmental Science and Technology, vol. 39, no. 5, pp. 12911298, 2005.

[311] S. R. Kanel, J.-M. Greneche, and H. Choi, "Arsenic(V) removal from groundwater using nano scale zero-valent iron as a colloidal reactive barrier material," Environmental Science and Technology, vol. 40, no. 6, pp. 2045-2050, 2006.

[312] G. C. C. Yang and H.-L. Lee, "Chemical reduction of nitrate by nanosized iron: kinetics and pathways," Water Research, vol. 39, no. 5, pp. 884-894, 2005.

[313] X.-Q. Li and W.-X. Zhang, "Iron nanoparticles: the coreshell structure and unique properties for $\mathrm{Ni}(\mathrm{II})$ sequestration," Langmuir, vol. 22, no. 10, pp. 4638-4642, 2006.

[314] W. Zhang, "Nanoscale iron particles for environmental remediation: an overview," Journal of Nanoparticle Research, vol. 5, no. 3-4, pp. 323-332, 2003. 
[315] L. S. Zhong, J. S. Hu, H. P. Liang, A. M. Cao, W. G. Song, and L. J. Wan, "Self-assembled 3D flowerlike iron oxide nanostructures and their application in water treatment," Advanced Materials, vol. 18, no. 18, pp. 2426-2431, 2006.

[316] L.-S. Zhong, J.-S. Hu, A.-M. Cao, Q. Liu, W.-G. Song, and L.-J. Wan, "3D flowerlike ceria micro/nanocomposite structure and its application for water treatment and CO removal," Chemistry of Materials, vol. 19, no. 7, pp. 1648-1655, 2007.

[317] N. Moreno, X. Querol, C. Ayora, C. F. Pereira, and M. JanssenJurkovicová, "Utilization of zeolites synthesized from coal fly ash for the purification of acid mine waters," Environmental Science and Technology, vol. 35, no. 17, pp. 3526-3534, 2001.

[318] E. Álvarez-Ayuso, A. García-Sánchez, and X. Querol, "Purification of metal electroplating waste waters using zeolites," Water Research, vol. 37, no. 20, pp. 4855-4862, 2003.

[319] M. S. Diallo, S. Christie, P. Swaminathan et al., "Dendritic chelating agents. 1. $\mathrm{Cu}$ (II) binding to ethylene diamine core poly(amidoamine) dendrimers in aqueous solutions," Langmuir, vol. 20, no. 7, pp. 2640-2651, 2004.

[320] S. V. Mattigod, X. Feng, G. E. Fryxell, J. Liu, and M. Gong, "Separation of complexed mercury from aqueous wastes using self-assembled mercaptan on mesoporous silica," Separation Science and Technology, vol. 34, no. 12, pp. 2329-2345, 1999.

[321] W. Yantasee, Y. Lin, G. E. Fryxell, B. J. Busche, and J. C. Birnbaum, "Removal of heavy metals from aqueous solution using novel nanoengineered sorbents: self-assembled carbamoylphosphonic acids on mesoporous silica," Separation Science and Technology, vol. 38, no. 15, pp. 3809-3825, 2003.

[322] S. V. Mattigod, G. E. Fryxell, X. Feng, K. E. Parker, and E. M. Piers, "Removal of mercury from aqueous streams of fossil fuel power plants using novel functionalized nanoporous sorbents," in Coal Combustion Byproducts and Environmental Issues, K. S. Sajwan, I. Twardowska, T. Punshon, and A. K. Alva, Eds., pp. 99-104, Springer, New York, NY, USA, 2006.

[323] J. Kostal, A. Mulchandani, and W. Chen, "Tunable biopolymers for heavy metal removal," Macromolecules, vol. 34, no. 7, pp. 2257-2261, 2001.

[324] J. Kostal, A. Mulchandani, K. E. Gropp, and W. Chen, "A temperature responsive biopolymer for mercury remediation," Environmental Science and Technology, vol. 37, no. 19, pp. 44574462, 2003.

[325] L. Qi and Z. Xu, "Lead sorption from aqueous solutions on chitosan nanoparticles," Colloids and Surfaces A: Physicochemical and Engineering Aspects, vol. 251, no. 1-3, pp. 183-190, 2004.

[326] B. Van Der Bruggen and C. Vandecasteele, "Removal of pollutants from surface water and groundwater by nanofiltration: overview of possible applications in the drinking water industry," Environmental Pollution, vol. 122, no. 3, pp. 435-445, 2003.

[327] A. Favre-Reguillon, G. Lebuzit, J. Foos, A. Guy, M. Draye, and M. Lemaire, "Selective concentration of uranium from seawater by nanofiltration," Industrial and Engineering Chemistry Research, vol. 42, no. 23, pp. 5900-5904, 2003.

[328] K. D. Hristovski, H. Nguyen, and P. K. Westerhoff, "Removal of arsenate and $17 \alpha$-ethinyl estradiol (EE2) by iron (hydr)oxide modified activated carbon fibers," Journal of Environmental Science and Health-Part A Toxic/Hazardous Substances and Environmental Engineering, vol. 44, no. 4, pp. 354-361, 2009.

[329] K. D. Hristovski, P. K. Westerhoff, T. Möller, and P. Sylvester, "Effect of synthesis conditions on nano-iron (hydr)oxide impregnated granulated activated carbon," Chemical Engineering Journal, vol. 146, no. 2, pp. 237-243, 2009.
[330] M. S. Diallo, S. Christie, P. Swaminathan, J. H. Johnson Jr., and W. A. Goddard III, "Dendrimer enhanced ultrafiltration.1. Recovery of $\mathrm{Cu}(\mathrm{II})$ from aqueous solutions using PAMAM dendrimers with ethylene diamine core and terminal $\mathrm{NH} 2$ groups," Environmental Science and Technology, vol. 39, no. 5, pp. 1366-1377, 2005.

[331] M. J. Aragon, R. L. Everett, M. D. Siegel et al., "Arsenic pilot plant operation and results," SAND 2007-6059, Sandia National Laboratories, Anthony, NM, USA, 2007.

[332] P. Sylvester, P. Westerhoff, T. Möller, M. Badruzzaman, and O. Boyd, "A hybrid sorbent utilizing nanoparticles of hydrous iron oxide for arsenic removal from drinking water," Environmental Engineering Science, vol. 24, no. 1, pp. 104-112, 2007.

[333] C. Charnock and O. Kjønnø, "Assimilable organic carbon and biodegradable dissolved organic carbon in Norwegian raw and drinking waters," Water Research, vol. 34, no. 10, pp. 2629-2642, 2000.

[334] J. Frias, F. Ribas, and F. Lucena, "Effects of different nutrients on bacterial growth in a pilot distribution system," Antonie van Leeuwenhoek, International Journal of General and Molecular Microbiology, vol. 80, no. 2, pp. 129-138, 2001.

[335] F. Li, A. Yuasa, K. Ebie, Y. Azuma, T. Hagishita, and Y. Matsui, "Factors affecting the adsorption capacity of dissolved organic matter onto activated carbon: modified isotherm analysis," Water Research, vol. 36, no. 18, pp. 4592-4604, 2002.

[336] M. J. Lehtola, T. Juhna, I. T. Miettinen, T. Vartiainen, and P. J. Martikainen, "Formation of biofilms in drinking water distribution networks, a case study in two cities in Finland and Latvia," Journal of Industrial Microbiology and Biotechnology, vol. 31, no. 11, pp. 489-494, 2004.

[337] B. Schreiber, T. Brinkmann, V. Schmalz, and E. Worch, "Adsorption of dissolved organic matter onto activated carbon-the influence of temperature, absorption wavelength, and molecular size," Water Research, vol. 39, no. 15, pp. 3449-3456, 2005.

[338] A. Matilainen, N. Vieno, and T. Tuhkanen, "Efficiency of the activated carbon filtration in the natural organic matter removal," Environment International, vol. 32, no. 3, pp. 324-331, 2006.

[339] C. Lu and F. Su, "Adsorption of natural organic matter by carbon nanotubes," Separation and Purification Technology, vol. 58, no. 1, pp. 113-121, 2007.

[340] S. A. Dastgheib, T. Karanfil, and W. Cheng, “Tailoring activated carbons for enhanced removal of natural organic matter from natural waters," Carbon, vol. 42, no. 3, pp. 547-557, 2004.

[341] P. A. Quinlivan, L. Li, and D. R. U. Knappe, "Effects of activated carbon characteristics on the simultaneous adsorption of aqueous organic micropollutants and natural organic matter," Water Research, vol. 39, no. 8, pp. 1663-1673, 2005.

[342] W. Cheng, S. A. Dastgheib, and T. Karanfil, "Adsorption of dissolved natural organic matter by modified activated carbons," Water Research, vol. 39, no. 11, pp. 2281-2290, 2005.

[343] H. Hyung and J.-H. Kim, "Natural organic matter (NOM) adsorption to multi-walled carbon nanotubes: effect of NOM characteristics and water quality parameters," Environmental Science and Technology, vol. 42, no. 12, pp. 4416-4421, 2008.

[344] N. B. Saleh, L. D. Pfefferle, and M. Elimelech, "Aggregation kinetics of multiwalled carbon nanotubes in aquatic systems: measurements and environmental implications," Environmental Science and Technology, vol. 42, no. 21, pp. 7963-7969, 2008.

[345] X. M. Yan, B. Y. Shi, J. J. Lu, C. H. Feng, D. S. Wang, and H. X. Tang, "Adsorption and desorption of atrazine on carbon 
nanotubes," Journal of Colloid and Interface Science, vol. 321, no. 1, pp. 30-38, 2008.

[346] T. G. Hedderman, S. M. Keogh, G. Chambers, and H. J. Byrne, "In-depth study into the interaction of single walled carbon nanotubes with anthracene and p-terphenyl," Journal of Physical Chemistry B, vol. 110, no. 9, pp. 3895-3901, 2006.

[347] K. Yang, L. Zhu, and B. Xing, "Adsorption of polycyclic aromatic hydrocarbons by carbon nanomaterials," Environmental Science and Technology, vol. 40, no. 6, pp. 1855-1861, 2006.

[348] S. Gotovac, C.-M. Yang, Y. Hattori, K. Takahashi, H. Kanoh, and K. Kaneko, "Adsorption of polyaromatic hydrocarbons on single wall carbon nanotubes of different functionalities and diameters," Journal of Colloid and Interface Science, vol. 314, no. 1, pp. 18-24, 2007.

[349] C. L. Mangun, Z. Yue, J. Economy, S. Maloney, P. Kemme, and D. Cropek, "Adsorption of organic contaminants from water using tailored ACFs," Chemistry of Materials, vol. 13, no. 7, pp. 23562360, 2001.

[350] X. Peng, Y. Li, Z. Luan et al., "Adsorption of 1,2-dichlorobenzene from water to carbon nanotubes," Chemical Physics Letters, vol. 376, no. 1-2, pp. 154-158, 2003.

[351] C. Lu, Y.-L. Chung, and K.-F. Chang, "Adsorption thermodynamic and kinetic studies of trihalomethanes on multiwalled carbon nanotubes," Journal of Hazardous Materials, vol. 138, no. 2, pp. 304-310, 2006.

[352] Y.-Q. Cai, Y.-E. Cai, S.-F. Mou, and Y.-Q. Lu, "Multi-walled carbon nanotubes as a solid-phase extraction adsorbent for the determination of chlorophenols in environmental water samples," Journal of Chromatography A, vol. 1081, no. 2, pp. 245$247,2005$.

[353] Q. Zhou, J. Xiao, and W. Wang, "Using multi-walled carbon nanotubes as solid phase extraction adsorbents to determine dichlorodiphenyltrichloroethane and its metabolites at trace level in water samples by high performance liquid chromatography with UV detection," Journal of Chromatography A, vol. 1125, no. 2, pp. 152-158, 2006.

[354] Q. Zhou, J. Xiao, W. Wang, G. Liu, Q. Shi, and J. Wang, "Determination of atrazine and simazine in environmental water samples using multiwalled carbon nanotubes as the adsorbents for preconcentration prior to high performance liquid chromatography with diode array detector," Talanta, vol. 68, no. 4, pp. 1309-1315, 2006.

[355] M. Zhou, P. R. Nemade, X. Lu et al., "New type of membrane material for water desalination based on a cross-linked bicontinuous cubic lyotropic liquid crystal assembly," Journal of the American Chemical Society, vol. 129, no. 31, pp. 9574-9575, 2007.

[356] J. Nawrocki and B. Kasprzyk-Hordern, "The efficiency and mechanisms of catalytic ozonation," Applied Catalysis B: Environmental, vol. 99, no. 1-2, pp. 27-42, 2010.

[357] C. A. Orge, J. J. M. Órfão, M. F. R. Pereira, A. M. Duarte de Farias, R. C. R. Neto, and M. A. Fraga, "Ozonation of model organic compounds catalysed by nanostructured cerium oxides," Applied Catalysis B: Environmental, vol. 103, no. 1-2, pp. 190-199, 2011.

[358] N. Chitose, S. Ueta, S. Seino, and T. A. Yamamoto, "Radiolysis of aqueous phenol solutions with nanoparticles. 1. Phenol degradation and TOC removal in solutions containing $\mathrm{TiO}_{2}$ induced by UV, $\gamma$-ray and electron beams," Chemosphere, vol. 50, no. 8, pp. 1007-1013, 2003.

[359] J. Jin, R. Li, H. Wang, H. Chen, K. Liang, and J. Ma, "Magnetic Fe nanoparticle functionalized water-soluble multi-walled carbon nanotubules towards the preparation of sorbent for aromatic compounds removal," Chemical Communications, no. 4, pp. 386-388, 2007.

[360] X. Han, Q. Kuang, M. Jin, Z. Xie, and L. Zheng, "Synthesis of titania nanosheets with a high percentage of exposed (001) facets and related photocatalytic properties," Journal of the American Chemical Society, vol. 131, no. 9, pp. 3152-3153, 2009.

[361] N. Murakami, Y. Kurihara, T. Tsubota, and T. Ohno, "Shapecontrolled anatase titanium(IV) oxide particles prepared by hydrothermal treatment of peroxo titanic acid in the presence of polyvinyl alcohol," Journal of Physical Chemistry C, vol. 113, no. 8, pp. 3062-3069, 2009.

[362] S. Liu, J. Yu, and M. Jaroniec, "Anatase $\mathrm{TiO}_{2}$ with dominant high-energy 001 facets: synthesis, properties, and applications," Chemistry of Materials, vol. 23, no. 18, pp. 4085-4093, 2011.

[363] S. Iwamoto, W. Tanakulrungsank, M. Inoue, K. Kagawa, and P. Praserthdam, "Synthesis of large-surface area silica-modified titania ultrafine particles by the glycothermal method," Journal of Materials Science Letters, vol. 19, no. 16, pp. 1439-1443, 2000.

[364] S. Iwamoto, S. Iwamoto, M. Inoue, H. Yoshida, T. Tanaka, and K. Kagawa, "XANES and XPS study of silica-modified titanias prepared by the glycothermal method," Chemistry of Materials, vol. 17, no. 3, pp. 650-655, 2005.

[365] H. Liu and L. Gao, "Synthesis and properties of CdSe-sensitized rutile $\mathrm{TiO}_{2}$ nanocrystals as a visible light-responsive photocatalyst," Journal of the American Ceramic Society, vol. 88, no. 4, pp. 1020-1022, 2005.

[366] L. Wu, J. C. Yu, and X. Fu, "Characterization and photocatalytic mechanism of nanosized CdS coupled $\mathrm{TiO}_{2}$ nanocrystals under visible light irradiation," Journal of Molecular Catalysis A: Chemical, vol. 244, no. 1-2, pp. 25-32, 2006.

[367] Y. Liu, X. Chen, J. Li, and C. Burda, "Photocatalytic degradation of azo dyes by nitrogen-doped $\mathrm{TiO}_{2}$ nanocatalysts," Chemosphere, vol. 61, no. 1, pp. 11-18, 2005.

[368] M. S. Nahar, K. Hasegawa, and S. Kagaya, "Photocatalytic degradation of phenol by visible light-responsive iron-doped $\mathrm{TiO}_{2}$ and spontaneous sedimentation of the $\mathrm{TiO}_{2}$ particles," Chemosphere, vol. 65, no. 11, pp. 1976-1982, 2006.

[369] D. Sun, T. T. Meng, T. H. Loong, and T. J. Hwa, "Removal of natural organic matter from water using a nano-structured photocatalyst coupled with filtration membrane," Water Science and Technology, vol. 49, no. 1, pp. 103-110, 2004.

[370] A. Tuel and L. G. Hubert-Pfalzgraf, "Nanometric monodispersed titanium oxide particles on mesoporous silica: synthesis, characterization, and catalytic activity in oxidation reactions in the liquid phase," Journal of Catalysis, vol. 217, no. 2, pp. 343-353, 2003.

[371] M.-J. López-Muñoz, R. V. Grieken, J. Aguado, and J. Marugán, "Role of the support on the activity of silica-supported $\mathrm{TiO}_{2}$ photocatalysts: structure of the $\mathrm{TiO}_{2}$ /SBA-15 photocatalysts," Catalysis Today, vol. 101, no. 3-4, pp. 307-314, 2005.

[372] X. Zhang, F. Zhang, and K.-Y. Chan, "Synthesis of titaniasilica mixed oxide mesoporous materials, characterization and photocatalytic properties," Applied Catalysis A: General, vol. 284, no. 1-2, pp. 193-198, 2005.

[373] M. Pratap Reddy, A. Venugopal, and M. Subrahmanyam, "Hydroxyapatite-supported $\mathrm{Ag}-\mathrm{TiO}_{2}$ as Escherichia coli disinfection photocatalyst," Water Research, vol. 41, no. 2, pp. 379386, 2007. 
[374] S. K. Samantaray, P. Mohapatra, and K. Parida, "Physicochemical characterisation and photocatalytic activity of nanosized SO42-/TiO2 towards degradation of 4-nitrophenol," Journal of Molecular Catalysis A: Chemical, vol. 198, no. 1-2, pp. 277287, 2003.

[375] Y. Chen, J. C. Crittenden, S. Hackney, L. Sutter, and D. W. Hand, "Preparation of a novel $\mathrm{TiO}_{2}$-based p-n junction nanotube photocatalyst," Environmental Science and Technology, vol. 39, no. 5, pp. 1201-1208, 2005.

[376] J. M. Macak, M. Zlamal, J. Krysa, and P. Schmuki, "Selforganized $\mathrm{TiO}_{2}$ nanotube layers as highly efficient photocatalysts," Small, vol. 3, no. 2, pp. 300-304, 2007.

[377] N. M. Al-Bastaki, "Performance of advanced methods for treatment of wastewater: $\mathrm{UV} / \mathrm{TiO}_{2}, \mathrm{RO}$ and UF," Chemical Engineering and Processing: Process Intensification, vol. 43, no. 7, pp. 935-940, 2004.

[378] M. J. Benotti, B. D. Stanford, E. C. Wert, and S. A. Snyder, "Evaluation of a photocatalytic reactor membrane pilot system for the removal of pharmaceuticals and endocrine disrupting compounds from water," Water Research, vol. 43, no. 6, pp. 15131522, 2009.

[379] P. Westerhoff, H. Moon, D. Minakata, and J. Crittenden, “Oxidation of organics in retentates from reverse osmosis wastewater reuse facilities," Water Research, vol. 43, no. 16, pp. 3992-3998, 2009.

[380] X. Zhao, L. Lv, B. Pan, W. Zhang, S. Zhang, and Q. Zhang, "Polymer-supported nanocomposites for environmental application: a review," Chemical Engineering Journal, vol. 170, no. 2-3, pp. 381-394, 2011.

[381] A. F. C. Campos, R. Aquino, T. A. P. G. Cotta, F. A. Tourinho, and J. Depeyrot, "Using speciation diagrams to improve synthesis of magnetic nanosorbents for environmental applications," Bulletin of Materials Science, vol. 34, no. 7, pp. 1357-1361, 2011.

[382] P. Li, D. E. Miser, S. Rabiei, R. T. Yadav, and M. R. Hajaligol, "The removal of carbon monoxide by iron oxide nanoparticles," Applied Catalysis B: Environmental, vol. 43, no. 2, pp. 151-162, 2003.

[383] R. Wu, J. Qu, and Y. Chen, "Magnetic powder $\mathrm{MnO}-\mathrm{Fe}_{2} \mathrm{O}_{3}$ composite-A novel material for the removal of azo-dye from water," Water Research, vol. 39, no. 4, pp. 630-638, 2005.

[384] S. Qiao, D. D. Sun, J. H. Tay, and C. Easton, "Photocatalytic oxidation technology for humic acid removal using a nanostructured $\mathrm{TiO}_{2} / \mathrm{Fe}_{2} \mathrm{O}_{3}$ catalyst," Water Science and Technology, vol. 47, no. 1, pp. 211-217, 2003.

[385] C.-B. Wang and W.-X. Zhang, "Synthesizing nanoscale iron particles for rapid and complete dechlorination of TCE and PCBs," Environmental Science and Technology, vol. 31, no. 7, pp. 2154-2156, 1997.

[386] W.-X. Zhang, C.-B. Wang, and H.-L. Lien, "Treatment of chlorinated organic contaminants with nanoscale bimetallic particles," Catalysis Today, vol. 40, no. 4, pp. 387-395, 1998.

[387] R. Cheng, J.-L. Wang, and W.-X. Zhang, "Comparison of reductive dechlorination of p-chlorophenol using $\mathrm{Fe} 0$ and nanosized Fe0," Journal of Hazardous Materials, vol. 144, no. 1-2, pp. 334-339, 2007.

[388] S. Choe, Y.-Y. Chang, K.-Y. Hwang, and J. Khim, "Kinetics of reductive denitrification by nanoscale zero-valent iron," Chemosphere, vol. 41, no. 8, pp. 1307-1311, 2000.

[389] J. Cao, D. Elliott, and W.-X. Zhang, "Perchlorate reduction by nanoscale iron particles," Journal of Nanoparticle Research, vol. 7, no. 4-5, pp. 499-506, 2005.
[390] S. Parra, S. E. Stanca, I. Guasaquillo, and K. Ravindranathan Thampi, "Photocatalytic degradation of atrazine using suspended and supported $\mathrm{TiO}_{2}$," Applied Catalysis B: Environmental, vol. 51, no. 2, pp. 107-116, 2004.

[391] J. Xu and D. Bhattacharyya, "Modeling of Fe/Pd nanoparticlebased functionalized membrane reactor for $\mathrm{PCB}$ dechlorination at room temperature," Journal of Physical Chemistry C, vol. 112, no. 25, pp. 9133-9144, 2008.

[392] Y. Xu and D. Zhao, "Reductive immobilization of chromate in water and soil using stabilized iron nanoparticles," Water Research, vol. 41, no. 10, pp. 2101-2108, 2007.

[393] B. Schrick, J. L. Blough, A. D. Jones, and T. E. Mallouk, "Hydrodechlorination of trichloroethylene to hydrocarbons using bimetallic nickel-iron nanoparticles," Chemistry of Materials, vol. 14, no. 12, pp. 5140-5147, 2002.

[394] J. T. Nurmi, P. G. Tratnyek, V. Sarathy et al., "Characterization and properties of metallic iron nanoparticles: spectroscopy, electrochemistry, and kinetics," Environmental Science and Technology, vol. 39, no. 5, pp. 1221-1230, 2005.

[395] H.-L. Lien and W.-X. Zhang, "Transformation of chlorinated methanes by nanoscale iron particles," Journal of Environmental Engineering, vol. 125, no. 11, pp. 1042-1047, 1999.

[396] S.-F. Cheng and S.-C. Wu, "The enhancement methods for the degradation of TCE by zero-valent metals," Chemosphere, vol. 41, no. 8, pp. 1263-1270, 2000.

[397] S.-F. Cheng and S.-C. Wu, "Feasibility of using metals to remediate water containing TCE," Chemosphere, vol. 43 , no. 8 , pp. 1023-1028, 2001.

[398] H.-L. Lien and W.-X. Zhang, "Nanoscale iron particles for complete reduction of chlorinated ethenes," Colloids and Surfaces A: Physicochemical and Engineering Aspects, vol. 191, no. 1-2, pp. 97105, 2001.

[399] F. He and D. Zhao, "Preparation and characterization of a new class of starch-stabilized bimetallic nanoparticles for degradation of chlorinated hydrocarbons in water," Environmental Science and Technology, vol. 39, no. 9, pp. 3314-3320, 2005.

[400] B.-W. Zhu, T.-T. Lim, and J. Feng, "Reductive dechlorination of 1,2,4-trichlorobenzene with palladized nanoscale $\mathrm{Fe} 0$ particles supported on chitosan and silica," Chemosphere, vol. 65, no. 7, pp. 1137-1145, 2006.

[401] J. Wei, X. Xu, Y. Liu, and D. Wang, "Catalytic hydrodechlorination of 2,4-dichlorophenol over nanoscale $\mathrm{Pd} / \mathrm{Fe}$ : reaction pathway and some experimental parameters," Water Research, vol. 40, no. 2, pp. 348-354, 2006.

[402] T.-T. Lim, J. Feng, and B.-W. Zhu, "Kinetic and mechanistic examinations of reductive transformation pathways of brominated methanes with nano-scale Fe and Ni/Fe particles," Water Research, vol. 41, no. 4, pp. 875-883, 2007.

[403] P. V. Kamat, R. Huehn, and R. Nicolaescu, "A "sense and shoot" approach for photocatalytic degradation of organic contaminants in water," Journal of Physical Chemistry B, vol. 106, no. 4, pp. 788-794, 2002.

[404] Z.-C. Wu, Y. Zhang, T.-X. Tao, L. Zhang, and H. Fong, "Silver nanoparticles on amidoxime fibers for photo-catalytic degradation of organic dyes in waste water," Applied Surface Science, vol. 257, no. 3, pp. 1092-1097, 2010.

[405] B. P. Chaplin, E. Roundy, K. A. Guy, J. R. Shapley, and C. I. Werth, "Effects of natural water ions and humic acid on catalytic nitrate reduction kinetics using an alumina supported $\mathrm{Pd}-\mathrm{Cu}$ catalyst," Environmental Science and Technology, vol. 40, no. 9, pp. 3075-3081, 2006. 
[406] H. Hildebrand, K. Mackenzie, and F.-D. Kopinke, "Novel nanocatalysts for wastewater treatment," Global Nest Journal, vol. 10, no. 1, pp. 47-53, 2008.

[407] M. O. Nutt, J. B. Hughes, and M. S. Wong, "Designing Pdon-Au bimetallic nanoparticle catalysts for trichloroethene hydrodechlorination," Environmental Science and Technology, vol. 39, no. 5, pp. 1346-1353, 2005.

[408] M. O. Nutt, K. N. Heck, P. Alvarez, and M. S. Wong, "Improved Pd-on-Au bimetallic nanoparticle catalysts for aqueous-phase trichloroethene hydrodechlorination," Applied Catalysis B: Environmental, vol. 69, no. 1-2, pp. 115-125, 2006.

[409] L. Espinal, S. L. Suib, and J. F. Rusling, "Electrochemical catalysis of styrene epoxidation with films of $\mathrm{MnO}_{2}$ nanoparticles and $\mathrm{H}_{2} \mathrm{O}_{2}$," Journal of the American Chemical Society, vol. 126, no. 24, pp. 7676-7682, 2004.

[410] J. Fei, Y. Cui, X. Yan et al., "Controlled preparation of MnO2 hierarchical hollow nanostructures and their application in water treatment," Advanced Materials, vol. 20, no. 3, pp. 452456, 2008.

[411] I. Dror, D. Baram, and B. Berkowitz, "Use of nanosized catalysts for transformation of chloro-organic pollutants," Environmental Science and Technology, vol. 39, no. 5, pp. 1283-1290, 2005.

[412] S. D. Kelly, K. M. Kemner, G. E. Fryxell, J. Liu, S. V. Mattigod, and K. F. Ferris, "X-ray-absorption fine-structure spectroscopy study of the interactions between contaminant tetrahedral anions and self-assembled monolayers on mesoporous supports," Journal of Physical Chemistry B, vol. 105, no. 27, pp. 63376346, 2001.

[413] G. E. Fryxell, Y. Lin, S. Fiskum et al., "Actinide sequestration using self-assembled monolayers on mesoporous supports," Environmental Science and Technology, vol. 39, no. 5, pp. 13241331, 2005.

[414] T. Schreiber, A. Weber, K. Niedergall et al., "Water treatment by molecularly imprinted polymer nanoparticles," in Proceedings of the MRS Spring Meeting \& Exhibit, pp. Q04-Q07, April 2009.

[415] J. Kim and J. W. Grate, "Nano-biotechnology in using enzymes for environmental remediation: single-enzyme nanoparticles," in Nanotechnology and the Environment: Applications and Implications, B. Karn, T. Masciangioli, W. Zhang, V. Colvin, and P. Alivisatos, Eds., vol. 890, pp. 220-225, American Chemical Society, Washington, DC, USA, 2004.

[416] J. Xu, L. Bachas, and D. Bhattacharyya, "Synthesis of nanostructured bimetallic particles in polyligand-functionalized membranes for remediation applications," in Nanotechnology Applications for Clean Water, N. Savage, M. Diallo, J. Duncan, A. Street, and R. Sustich, Eds., chapter 22, pp. 311-335, William Andrew, Boston, Mass, USA, 2009.

[417] H. Choi, E. Stathatos, and D. D. Dionysiou, "Sol-gel preparation of mesoporous photocatalytic $\mathrm{TiO}_{2}$ films and $\mathrm{TiO}_{2} / \mathrm{Al}_{2} \mathrm{O}_{3}$ composite membranes for environmental applications," Applied Catalysis B: Environmental, vol. 63, no. 1-2, pp. 60-67, 2006.

[418] L. Wu and S. M. C. Ritchie, "Enhanced dechlorination of trichloroethylene by membrane-supported Pd-coated iron nanoparticles," Environmental Progress, vol. 27, no. 2, pp. 218224, 2008.

[419] H. F. Lin, R. Ravikrishna, and K. T. Valsaraj, "Reusable adsorbents for dilute solution separation. 6. Batch and continuous reactors for the adsorption and degradation of 1,2dichlorobenzene from dilute wastewater streams using titania as a photocatalyst," Separation and Purification Technology, vol. 28, no. 2, pp. 87-102, 2002.
[420] R. Molinari, L. Palmisano, E. Drioli, and M. Schiavello, "Studies on various reactor configurations for coupling photocatalysis and membrane processes in water purification," Journal of Membrane Science, vol. 206, no. 1-2, pp. 399-415, 2002.

[421] Y. Yang, H. Zhang, P. Wang, Q. Zheng, and J. Li, “The influence of nano-sized $\mathrm{TiO}_{2}$ fillers on the morphologies and properties of PSF UF membrane," Journal of Membrane Science, vol. 288, no. 1-2, pp. 231-238, 2007.

[422] A. Rahimpour, S. S. Madaeni, A. H. Taheri, and Y. Mansourpanah, "Coupling $\mathrm{TiO}_{2}$ nanoparticles with UV irradiation for modification of polyethersulfone ultrafiltration membranes," Journal of Membrane Science, vol. 313, no. 1-2, pp. 158-169, 2008.

[423] G. Wu, S. Gan, L. Cui, and Y. Xu, "Preparation and characterization of $\mathrm{PES} / \mathrm{TiO}_{2}$ composite membranes," Applied Surface Science, vol. 254, no. 21, pp. 7080-7086, 2008.

[424] G. C. C. Yang and C.-J. Li, "Preparation of tubular $\mathrm{TiO}_{2} / \mathrm{Al}_{2} \mathrm{O}_{3}$ composite membranes and their performance in electrofiltration of oxide-CMP wastewater," Desalination, vol. 200, no. 1-3, pp. 74-76, 2006.

[425] Q. Zhang, Y. Fan, and N. Xu, "Effect of the surface properties on filtration performance of $\mathrm{Al} 2 \mathrm{O} 3-\mathrm{TiO} 2$ composite membrane," Separation and Purification Technology, vol. 66, no. 2, pp. 306312, 2009.

[426] L. Wu, M. Shamsuzzoha, and S. M. C. Ritchie, "Preparation of cellulose acetate supported zero-valent iron nanoparticles for the dechlorination of trichloroethylene in water," Journal of Nanoparticle Research, vol. 7, no. 4-5, pp. 469-476, 2005.

[427] D. E. Meyer, K. Wood, L. G. Bachas, and D. Bhattacharyya, "Degradation of chlorinated organics by membrane-immobilized nanosized metals," Environmental Progress, vol. 23, no. 3, pp. 232-242, 2004.

[428] L. Wu and S. M. C. Ritchie, "Removal of trichloroethylene from water by cellulose acetate supported bimetallic Ni/Fe nanoparticles," Chemosphere, vol. 63, no. 2, pp. 285-292, 2006.

[429] J. Xu and D. Bhattacharyya, "Fe/Pd nanoparticle immobilization in microfiltration membrane pores: synthesis, characterization, and application in the dechlorination of polychlorinated biphenyls," Industrial and Engineering Chemistry Research, vol. 46, no. 8, pp. 2348-2359, 2007.

[430] V. V. Tarabara, "Multifunctional nanomaterial-enabled membranes for water treatment," in Nanotechnology Applications for Clean Water, N. Savage, M. Diallo, J. Duncan, A. Street, and R. Sustich, Eds., chapter 5, pp. 59-75, William Andrew, Boston, Mass, USA, 2009.

[431] J. Xu and D. Bhattacharyya, "Membrane-based bimetallic nanoparticles for environmental remediation: synthesis and reactive properties," Environmental Progress, vol. 24, no. 4, pp. 358-366, 2005.

[432] K. Venkatachalam, X. Arzuaga, N. Chopra et al., "Reductive dechlorination of $3,3^{\prime}, 4,4^{\prime}$-tetrachlorobiphenyl (PCB77) using palladium or palladium/iron nanoparticles and assessment of the reduction in toxic potency in vascular endothelial cells," Journal of Hazardous Materials, vol. 159, no. 2-3, pp. 483-491, 2008.

[433] B. S. Karnik, S. H. R. Davies, K. C. Chen, D. R. Jaglowski, M. J. Baumann, and S. J. Masten, "Effects of ozonation on the permeate flux of nanocrystalline ceramic membranes," Water Research, vol. 39, no. 4, pp. 728-734, 2005.

[434] H. Verweij, M. C. Schillo, and J. Li, "Fast mass transport through carbon nanotube membranes," Small, vol. 3, no. 12, pp. 19962004, 2007. 
[435] G. C. C. Yang and C.-M. Tsai, "Preparation of carbon fibers/carbon/alumina tubular composite membranes and their applications in treating Cu-CMP wastewater by a novel electrochemical process," Journal of Membrane Science, vol. 321, no. 2, pp. 232-239, 2008.

[436] Y. Yao, G. Li, K. A. Gray, and R. M. Lueptow, "Single-walled carbon nanotube-facilitated dispersion of particulate $\mathrm{TiO}_{2}$ on $\mathrm{ZrO}_{2}$ ceramic membrane filters," Langmuir, vol. 24, no. 14, pp. 7072-7075, 2008.

[437] S. Peltier, M. Cotte, D. Gatel, L. Herremans, and J. Cavard, "Nanofiltration: improvements of water quality in a large distribution system," Water Science and Technology: Water Supply, vol. 3, no. 1-2, pp. 193-200, 2003.

[438] G. L. Jadav and P. S. Singh, "Synthesis of novel silica-polyamide nanocomposite membrane with enhanced properties," Journal of Membrane Science, vol. 328, no. 1-2, pp. 257-267, 2009.

[439] M. F. Ottaviani, P. Favuzza, M. Bigazzi, N. J. Turro, S. Jockusch, and D. A. Tomalia, "A TEM and EPR investigation of the competitive binding of uranyl ions to starburst dendrimers and liposomes: potential use of dendrimers as uranyl ion sponges," Langmuir, vol. 16, no. 19, pp. 7368-7372, 2000.

[440] E. R. Birnbaum, K. C. Rau, and N. N. Sauer, "Selective anion binding from water using soluble polymers," Separation Science and Technology, vol. 38, no. 2, pp. 389-404, 2003.

[441] A. Bottino, G. Capannelli, V. D'Asti, and P. Piaggio, "Preparation and properties of novel organic-inorganic porous membranes," Separation and Purification Technology, vol. 22-23, pp. 269-275, 2001.

[442] K. Ebert, D. Fritsch, J. Koll, and C. Tjahjawiguna, "Influence of inorganic fillers on the compaction behaviour of porous polymer based membranes," Journal of Membrane Science, vol. 233, no. 1-2, pp. 71-78, 2004.

[443] T.-H. Bae and T.-M. Tak, "Effect of $\mathrm{TiO}_{2}$ nanoparticles on fouling mitigation of ultrafiltration membranes for activated sludge filtration," Journal of Membrane Science, vol. 249, no. 12, pp. 1-8, 2005.

[444] N. Maximous, G. Nakhla, K. Wong, and W. Wan, "Optimization of $\mathrm{Al}_{2} \mathrm{O}_{3} / \mathrm{PES}$ membranes for wastewater filtration," Separation and Purification Technology, vol. 73, no. 2, pp. 294-301, 2010.

[445] M. T. M. Pendergast, J. M. Nygaard, A. K. Ghosh, and E. M. V. Hoek, "Using nanocomposite materials technology to understand and control reverse osmosis membrane compaction," Desalination, vol. 261, no. 3, pp. 255-263, 2010. 

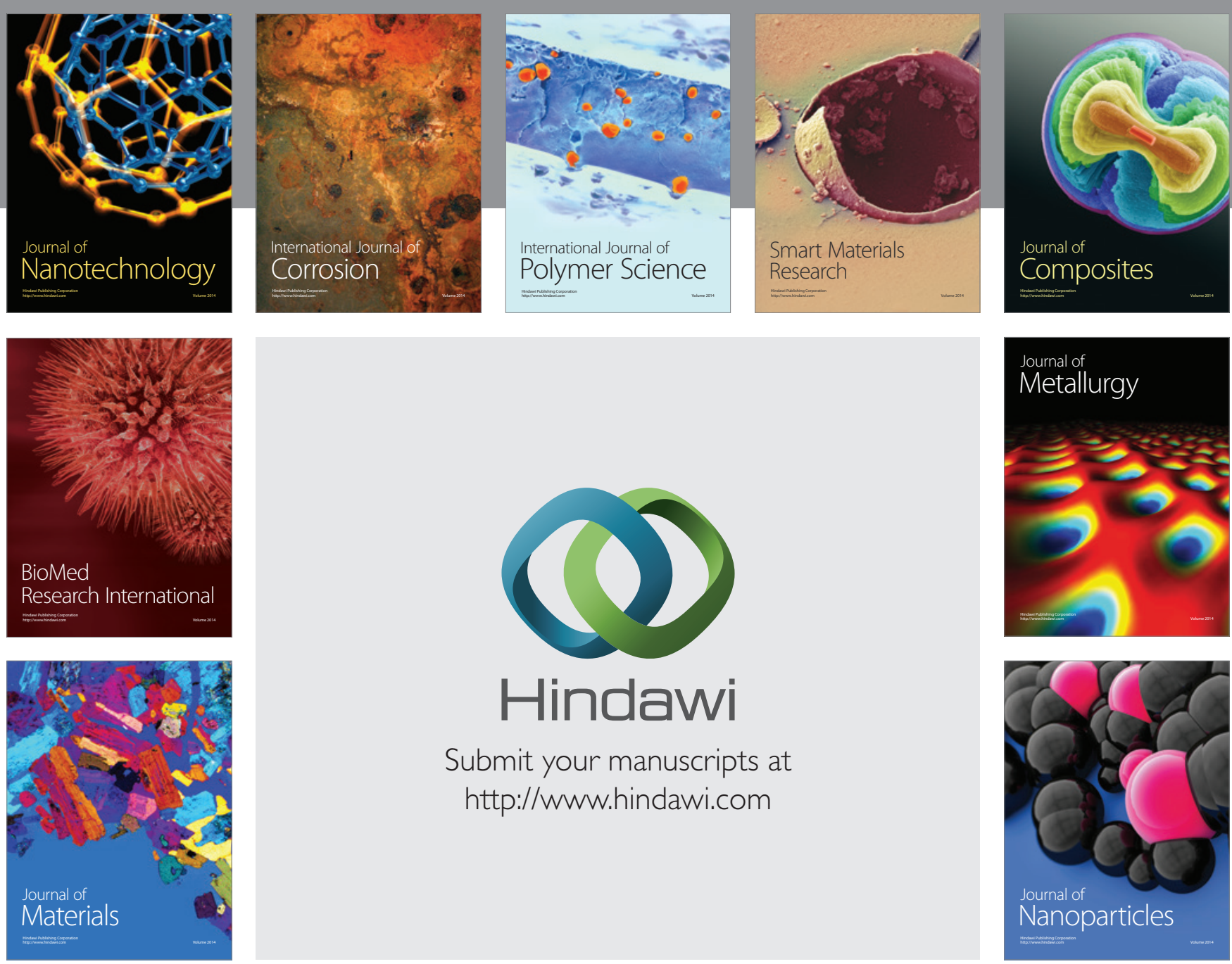

Submit your manuscripts at http://www.hindawi.com
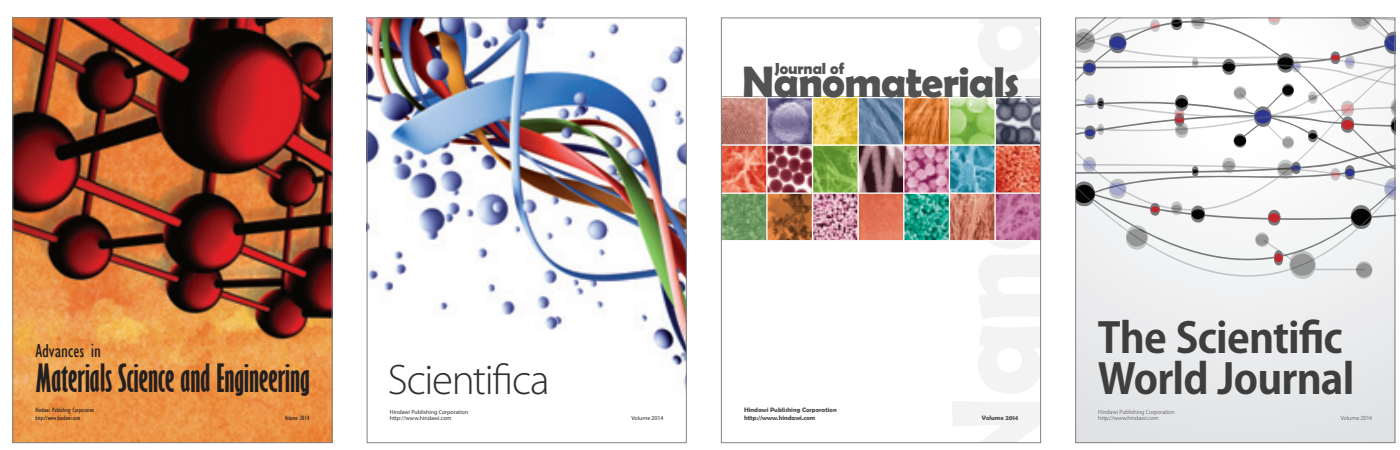

\section{The Scientific World Journal}
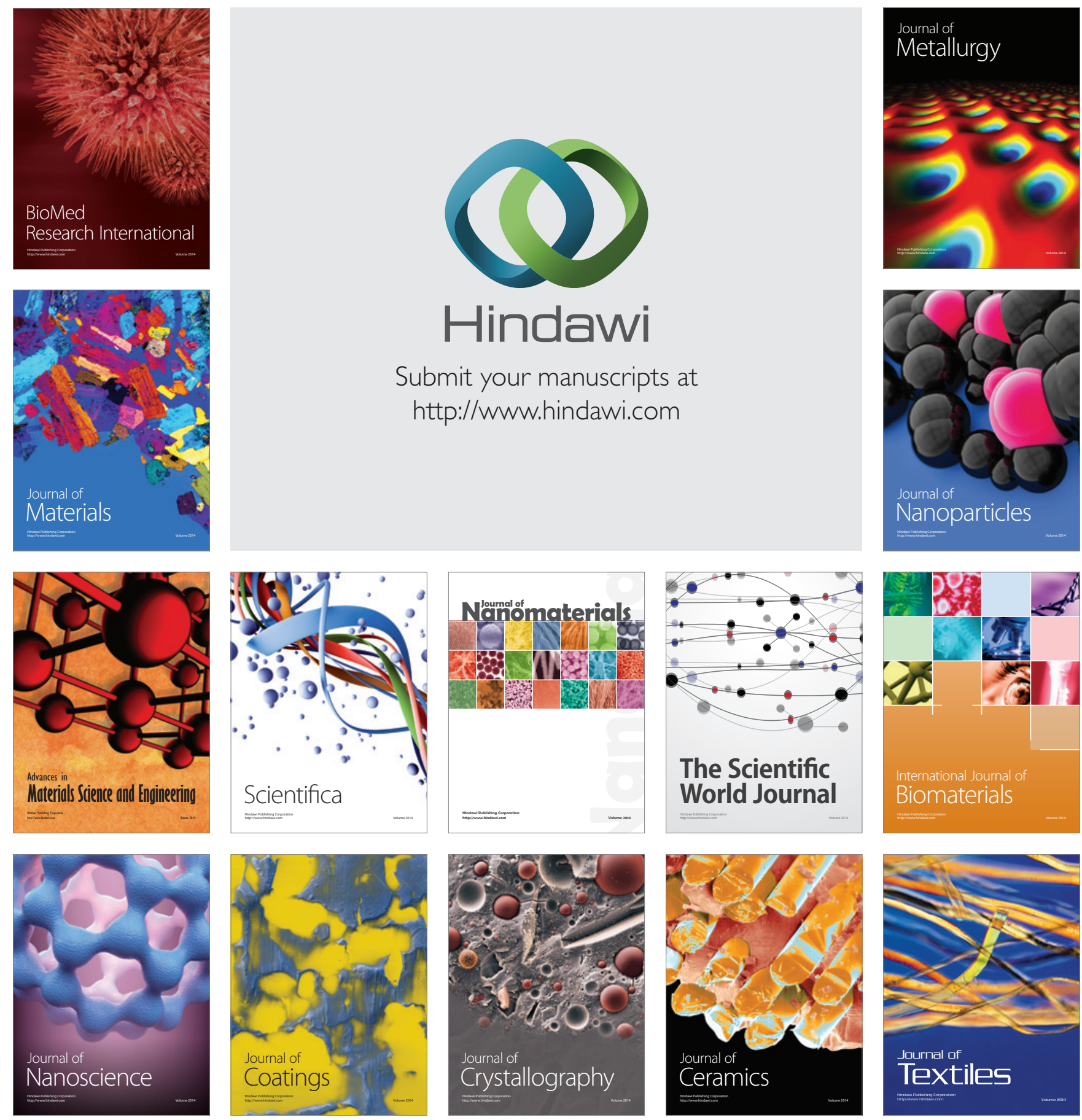